\title{
Highly Electroactive Ni Pyrophosphate/Pt Catalyst toward Hydrogen Evolution Reaction
}

\author{
Jayaraman Theerthagiri, ${ }^{\ddagger} \dagger$ Eduardo S. F. Cardoso, ${ }^{\S \dagger}$ Guilherme V. Fortunato, ${ }^{\S, \dagger}$ \\ Gleison A. Casagrande, ${ }^{\S}$ Baskar Senthilkumar, ${ }^{\|}$Jagannathan Madhavan, ${ }^{\perp}{ }^{(0)}$ and Gilberto Maia ${ }^{*},{ }^{(0)}$ \\ ${ }^{\ddagger}$ Centre of Excellence for Energy Research, Sathyabama Institute of Science and Technology (Deemed to be University), Chennai \\ 600119, India \\ ${ }^{\S}$ Institute of Chemistry, Universidade Federal de Mato Grosso do Sul, Senador Filinto Muller Avenue, 1555, Campo Grande, Mato \\ Grosso do Sul 79074-460, Brazil \\ "Materials Research Centre, Indian Institute of Science, Bangalore 560012, India \\ ${ }^{\perp}$ Solar Energy Lab, Department of Chemistry, Thiruvalluvar University, Vellore 632115, Tamil Nadu, India
}

Supporting Information

\begin{abstract}
Robust electrocatalysts toward the resourceful and sustainable generation of hydrogen by splitting of water via electrocatalytic hydrogen evolution reaction (HER) are a prerequisite to realize high-efficiency energy research. Highly electroactive catalysts for hydrogen production with ultralow loading of platinum $(\mathrm{Pt})$ have been under exhaustive exploration to make them cutting-edge and cost-effectively reasonable for water splitting. Herein, we report the synthesis of hierarchically structured nickel pyrophosphate $\left(\beta-\mathrm{Ni}_{2} \mathrm{P}_{2} \mathrm{O}_{7}\right)$ by a precipitation method and nickel phosphate $\left(\mathrm{Ni}_{3}\left(\mathrm{PO}_{4}\right)_{2}\right)$

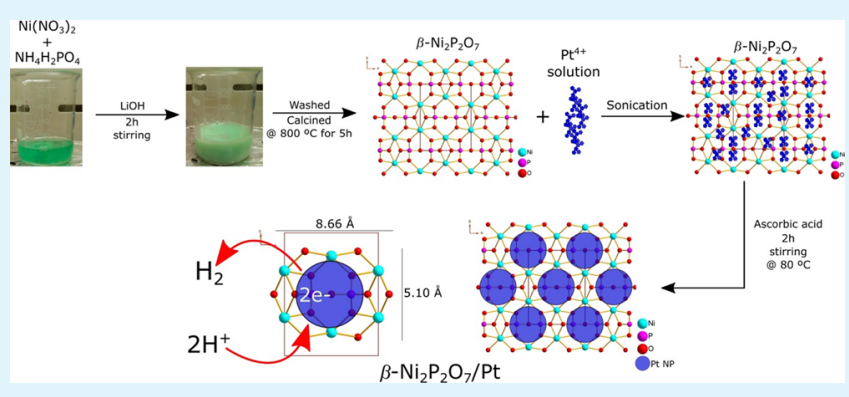
by two different synthetic routes, namely, simple cost-effective precipitation and solution combustion processes. Thereafter, Pt-decorated nickel pyrophosphate and nickel phosphate $(\beta$ $\mathrm{Ni}_{2} \mathrm{P}_{2} \mathrm{O}_{7} / \mathrm{Pt}$ and $\left.\mathrm{Ni}_{3}\left(\mathrm{PO}_{4}\right)_{2} / \mathrm{Pt}\right)$ were prepared by using potassium hexachloroplatinate and ascorbic acid. The fabricated novel nickel pyrophosphate and nickel phosphate/Pt materials were utilized as potential and affordable electrocatalysts for HER by water splitting. The detailed electrochemical studies revealed that the $\beta-\mathrm{Ni}_{2} \mathrm{P}_{2} \mathrm{O}_{7} / \mathrm{Pt}\left(1 \mu \mathrm{g} \cdot \mathrm{cm}^{-2} \mathrm{Pt}\right)$ electrocatalyst showed excellent electrocatalytic performances for HER in acidic solution with an overpotential of $28 \mathrm{mV}$ at $-10 \mathrm{~mA} \cdot \mathrm{cm}^{-2}$, a Tafel slope of $32 \mathrm{mV} \cdot \mathrm{dec}$, and an exchange current density $\left(j_{0}\right)$ of $-1.31 \mathrm{~mA} \cdot \mathrm{cm}^{-2}$, which were close to the values obtained using the Vulcan $/ \mathrm{Pt}\left(8.0 \mu \mathrm{g} \cdot \mathrm{cm}^{-2} \mathrm{Pt}\right)$, commercial benchmarking electrocatalyst with eight times higher Pt amount. Furthermore, the $\beta$ $\mathrm{Ni}_{2} \mathrm{P}_{2} \mathrm{O}_{7} / \mathrm{Pt}$ electrocatalyst maintains an excellent stability for over $-0.1 \mathrm{~V}$ versus RHE for 12 days, keeping $j_{0}$ equal after the stability test $\left(-1.28 \mathrm{~mA} \mathrm{~cm}{ }^{-2}\right)$. Very well-distributed Pt NPs inside the "cages" on the $\beta-\mathrm{Ni}_{2} \mathrm{P}_{2} \mathrm{O}_{7}$ structure with a crystalline pattern of $0.67 \mathrm{~nm}$ distance to the $\mathrm{Ni}_{2} \mathrm{P}_{2} \mathrm{O}_{7} / \mathrm{Pt}$ electrocatalyst, helping the Volmer-Tafel mechanism with the Tafel reaction as a major rate-limiting step, help to liberate very fast the Pt sites after HER. The high electrocatalytic performance and remarkable durability showed the $\beta-\mathrm{Ni}_{2} \mathrm{P}_{2} \mathrm{O}_{7} / \mathrm{Pt}$ material to be a promising cost-effective electrocatalyst for hydrogen production.
\end{abstract}

KEYWORDS: hydrogen evolution reaction, nickel, phosphate, platinum, pyrophosphate

\section{INTRODUCTION}

Hydrogen $\left(\mathrm{H}_{2}\right)$ is the cleanest energy transporter to the hydrogen-based economy and has gained an increasing attention as a substitute for fossil fuels. Resourceful and sustainable generation of $\mathrm{H}_{2}$ is crucial for a hydrogen economy to diminish our reliance on fossil fuels and their harmful environmental impacts. ${ }^{1-3}$ Commercially, the generation of $\mathrm{H}_{2}$ is obtained from methane steam reforming and gasification of coal. However, these two methods have ecological consequences as well as engaged with more cost, which stimulated an extensive attempt to explore clean energy sources. In this pursuit, the sustainable production of $\mathrm{H}_{2}$ by splitting of water via electrocatalytic hydrogen evolution reaction (HER) has fascinated significant attention because of its characteristics such as low cost, easy fabrication process, high efficiency, environmental friendly, carbon free, and large scale production. ${ }^{4-6}$ In the electrocatalytic HER, protons and electrons are combined to generate $\mathrm{H}_{2}$, being catalyzed by electrochemically active catalysts, with a high current density at a low overpotential. ${ }^{7}$ Commonly, platinum is the most extensively utilized electrocatalyst for HER in acid media because of its high stability, low Gibbs free energy $\left(\Delta G_{\mathrm{H}} *\right)$ for $\mathrm{H}_{2}$ adsorption, and superior electrocatalytic performances. However, noble Pt strongly hinders its broad commercialization for

Received: October 17, 2018

Accepted: January 9, 2019

Published: January 9, 2019 
the large scale $\mathrm{H}_{2}$ generation because of its high price and little abundance in earth. Thus, this prompted the development of advanced alternative electrocatalysts for HER with costeffectiveness and also the maintenance of high electrocatalytic performances toward the production of $\mathrm{H}_{2}$.

More recently, nickel-based electrocatalysts such as nickel phosphide, ${ }^{8}$ nickel sulfide, ${ }^{9}$ nickel selenide, ${ }^{10} \mathrm{Ni}-\mathrm{MoC}_{x} /$ carbon black, ${ }^{11}$ and $\mathrm{Ni} @ \mathrm{Ni}(\mathrm{OH})_{2} / \mathrm{Pd} / \mathrm{rGO}^{12}$ have been utilized for $\mathrm{H}_{2}$ production in acidic media. However, none of other catalyst has achieved an HER activity attained from Pt-based electrocatalysts. In this context, researchers made an alternative solution to this standoff, which was to search substitute electrocatalysts by minimizing the dosage of platinum. ${ }^{13-16}$ For example, Wang et al. ${ }^{17}$ developed $\mathrm{Ni}(\mathrm{OH})_{2}$-supported $\mathrm{Pt} /$ $\mathrm{C}$ electrocatalysis for $\mathrm{H}_{2}$ production. The $\mathrm{Pt} / \mathrm{Ni}(\mathrm{OH})_{2}$ hybrids could significantly enhance the activity of a pure $\mathrm{Pt}$ electrocatalyst for HER performance. In addition, the transition metal hydroxides exhibited good adsorption capabilities for $\mathrm{OH}^{-}$, produced after the dissociation of water by creating $\mathrm{OH}^{-}$and $\mathrm{H}^{+}$. Rapid adsorption of $\mathrm{OH}^{-}$results in rapid desorption of $\mathrm{OH}^{-}$from the surface of $\mathrm{Pt}$, which would be used further to enhance the activity of HER performance. Another report by Zheng ${ }^{18}$ investigated the electrocatalytic activity of $\mathrm{PtNi}_{x}$ by alteration of stoichiometric ratio of $\mathrm{Pt} / \mathrm{Ni}$. As a result, the maximized electrocatalytic performances were achieved for $\mathrm{PtNi}_{5}$ composition toward the HER activity. On the basis of the $\mathrm{H}_{2}$ adsorption theory, the $\Delta G_{\mathrm{H}} *$ value of $\mathrm{Ni}$ is closer to zero when compared with Mo, Co, W, and so forth, as a result the alloying of $\mathrm{Pt}$ and $\mathrm{Ni}$ is predictable to enhance the electrocatalytic behavior toward HER.

In this work, we have synthesized hierarchically structured $\beta$ $\mathrm{Ni}_{2} \mathrm{P}_{2} \mathrm{O}_{7}, \mathrm{Ni}_{3}\left(\mathrm{PO}_{4}\right)_{2}$, and $\mathrm{Ni}_{3}\left(\mathrm{PO}_{4}\right)_{2}{ }^{\prime}$ by simple cost-effective methods such as precipitation and solution combustion methods, respectively. In a second step, we have developed Pt-assisted $\beta-\mathrm{Ni}_{2} \mathrm{P}_{2} \mathrm{O}_{7}, \mathrm{Ni}_{3}\left(\mathrm{PO}_{4}\right)_{2}$, and $\mathrm{Ni}_{3}\left(\mathrm{PO}_{4}\right)_{2}^{\prime}$ composites $\left(\beta-\mathrm{Ni}_{2} \mathrm{P}_{2} \mathrm{O}_{7} / \mathrm{Pt}, \mathrm{Ni}_{3}\left(\mathrm{PO}_{4}\right)_{2} / \mathrm{Pt}\right.$, and $\left.\mathrm{Ni}_{3}\left(\mathrm{PO}_{4}\right)_{2}{ }^{\prime} / \mathrm{Pt}\right)$ as advanced electrocatalysts for the $\mathrm{H}_{2}$ production. To the best of our knowledge and to the extent advancement in this field concerned, this is the first time report on Pt-assisted nickel pyrophosphate and nickel phosphate as electrocatalysts toward HER activity. This present study will display a high electrocatalytic HER activity from low amount of Pt (see Table S1 in Supporting Information for a fast overview/ comparison with different materials reported in the literature $)^{4,6,8,13,14,19-31}$ and contribute to an advancement of superior electrocatalysts with low cost for $\mathrm{H}_{2}$ production. The appealing results obtained in materials characterization and electrocatalytic performances are systematically highlighted.

\section{EXPERIMENTAL SECTION}

Reagents and Instruments. The precursor solutions and metal salts utilized nickel nitrate hexahydrate $\left(\mathrm{Ni}\left(\mathrm{NO}_{3}\right)_{2} \cdot 6 \mathrm{H}_{2} \mathrm{O}\right)$, ammonium dihydrogen phosphate $\left(\mathrm{NH}_{4} \mathrm{H}_{2} \mathrm{PO}_{4}\right)$, lithium hydroxide $(\mathrm{LiOH})$, sodium hydroxide pellets $(\mathrm{NaOH})$ and urea $\left(\mathrm{NH}_{2} \mathrm{CONH}_{2}\right)$ were purchased from Sigma-Aldrich. Potassium hexachloroplatinate $\left(\mathrm{K}_{2} \mathrm{PtCl}_{6}\right)$, ascorbic acid (AA), sulfuric acid $\left(\mathrm{H}_{2} \mathrm{SO}_{4}\right)$, and $\mathrm{CuSO}_{4}$. $5 \mathrm{H}_{2} \mathrm{O}$ were obtained from Vetec, and $20 \% \mathrm{Pt}$ on Vulcan XC72 (20 wt $\%$ loading Pt/Vulcan, named Vulcan/Pt) was purchased from SigmaAldrich. All reagents utilized in this investigation were used as received.

A typical three-electrode setup of the glass cell used during voltammetric and chronoamperometric measurements contains the following: working electrode, a Teflon-embedded glassy carbon (GC) disk $\left(0.196 \mathrm{~cm}^{2}\right.$ in geometric area) or a Teflon-embedded Pt disk
(0.164 $\mathrm{cm}^{2}$ in geometric area) (Pine Research Instrumentation) or a carbon paper HCP030N $\left(1.0 \mathrm{~cm}^{2}\right)$ or a carbon graphite plate $(1.0$ $\left.\mathrm{cm}^{2}\right)$; reference electrode, RHE; and counter electrode, a carbon paper HCP030N $\left(3.5 \mathrm{~cm}^{2}\right)$.

Synthesis of Nickel Pyrophosphate by Precipitation Process. Nickel pyrophosphate $\left(\beta-\mathrm{Ni}_{2} \mathrm{P}_{2} \mathrm{O}_{7}\right)$ was synthesized by easy and low-cost precipitation process. For an instance, calculated stoichiometric quantity of $\mathrm{Ni}\left(\mathrm{NO}_{3}\right)_{2} \cdot 6 \mathrm{H}_{2} \mathrm{O}(1.08 \mathrm{~mol})$ and $\mathrm{NH}_{4} \mathrm{H}_{2} \mathrm{PO}_{4}(1 \mathrm{~mol})$ was dissolved in $50 \mathrm{~mL}$ of distilled water. Then, $30 \mathrm{~mL}$ of LiOH ( $2 \mathrm{~mol}$ ) solution was introduced dropwise as a precipitating agent under constant magnetic stirring. The resulting mixture was stirred well for overnight in a magnetic stirrer. The final precipitate was collected by centrifugation and washed several times with distilled water. ${ }^{32}$ Then, the obtained sample was calcined at 800 ${ }^{\circ} \mathrm{C}$ for $5 \mathrm{~h}$ (Scheme S1).

Synthesis of Nickel Phosphate by Precipitation Process. For the synthesis of nickel phosphate $\left(\mathrm{Ni}_{3}\left(\mathrm{PO}_{4}\right)_{2}\right)$, the calculated stoichiometric quantity of $\mathrm{Ni}\left(\mathrm{NO}_{3}\right)_{2} \cdot 6 \mathrm{H}_{2} \mathrm{O}(3 \mathrm{~mol})$ and $\mathrm{NH}_{4} \mathrm{H}_{2} \mathrm{PO}_{4}(2 \mathrm{~mol})$ was uniformly dissolved in $50 \mathrm{~mL}$ of doubledistilled water, and the $\mathrm{pH}$ of the reaction mixture was adjusted to 7 by using $1 \mathrm{M} \mathrm{NaOH}$. The obtained reaction mixture was magnetically stirred for about $5 \mathrm{~h}$. After the completion of the reaction, the acquired precipitate was washed several times using deionized water and then dried at $80{ }^{\circ} \mathrm{C}$ for overnight. Finally, the obtained product was calcined at $700{ }^{\circ} \mathrm{C}$ for $5 \mathrm{~h}$.

Synthesis of Nickel Phosphate by Solution Combustion Process. Nickel phosphate $\left(\mathrm{Ni}_{3}\left(\mathrm{PO}_{4}\right)_{2}{ }^{\prime}\right)$ was synthesized by a simple solution combustion process. For the synthesis, $4.37 \mathrm{~g}$ of $\mathrm{Ni}\left(\mathrm{NO}_{3}\right)_{2}$. $6 \mathrm{H}_{2} \mathrm{O}$ and $1.70 \mathrm{~g}$ of $\mathrm{NH}_{4} \mathrm{H}_{2} \mathrm{PO}_{4}$ were dissolved in double-distilled water and followed by the addition of $\mathrm{NH}_{2} \mathrm{CONH}_{2}$. Urea was used as fuel. All precursor materials were thoroughly dissolved using doubledistilled water $(20 \mathrm{~mL})$ with constant magnetic stirring to obtain homogenous solution. Then, the obtained reaction mixture was kept on hot plate at $200{ }^{\circ} \mathrm{C}$ for dehydration. After complete dehydration, the resulting solid was transferred to a muffle furnace and heat-treated around $300{ }^{\circ} \mathrm{C}$. After $10 \mathrm{~min}$, the decomposition with gradual release of gases was observed. The final foamy product was collected after grinding it on an agate mortar pestle and used for further characterization. The foamy product was calcined at $800{ }^{\circ} \mathrm{C}$ for $5 \mathrm{~h}$.

The synthesized materials were denoted in this study as nickel pyrophosphate $\left(\beta-\mathrm{Ni}_{2} \mathrm{P}_{2} \mathrm{O}_{7}\right)$ "precipitation", nickel phosphate $\left(\mathrm{Ni}_{3}\left(\mathrm{PO}_{4}\right)_{2}\right)$ "precipitation", and nickel phosphate $\left(\mathrm{Ni}_{3}\left(\mathrm{PO}_{4}\right)_{2}{ }^{\prime}\right)$ "solution combustion".

Syntheses of $\beta-\mathrm{Ni}_{2} \mathrm{P}_{2} \mathrm{O}_{7} / \mathrm{Pt}, \mathrm{Ni}_{3}\left(\mathrm{PO}_{4}\right)_{2} / \mathrm{Pt}, \mathrm{Ni}_{3}\left(\mathrm{PO}_{4}\right)_{2}{ }^{\prime} / \mathrm{Pt}$, and Pt Nanoparticles (Pt NPs). Initially, in a beaker, $10 \mathrm{mg}$ of $\beta$ $\mathrm{Ni}_{2} \mathrm{P}_{2} \mathrm{O}_{7}\left(\right.$ or $\mathrm{Ni}_{3}\left(\mathrm{PO}_{4}\right)_{2}$ or $\left.\mathrm{Ni}_{3}\left(\mathrm{PO}_{4}\right)_{2}^{\prime}\right)$ and $1.56 \mathrm{mg}$ of $\mathrm{K}_{2} \mathrm{PtCl}_{6}$ (or $0.78 \mathrm{mg}$ of $\mathrm{K}_{2} \mathrm{PtCl}_{6}$ or $0.39 \mathrm{mg}$ of $\mathrm{K}_{2} \mathrm{PtCl}_{6}$ only to $\beta-\mathrm{Ni}_{2} \mathrm{P}_{2} \mathrm{O}_{7}$ ) or only $1.56 \mathrm{mg}$ of $\mathrm{K}_{2} \mathrm{PtCl}_{6}$ were mixed with $20 \mathrm{~mL}$ of Milli- $\mathrm{Q}$ water; then, the reaction mixture was sonicated for at least $20 \mathrm{~min}$. Posteriorly, the dispersion was heated to $80{ }^{\circ} \mathrm{C}$ on a hotplate under constant magnetic stirring. When the temperature reached $80{ }^{\circ} \mathrm{C}, 2.65 \mathrm{mg}$ (or 1.33 or $0.6 \mathrm{mg}$ when was the case) of ascorbic acid was added (solubilized in $1 \mathrm{~mL}$ of Milli-Q water) to reduce the Pt ions, and the stirring and heating were maintained for $2 \mathrm{~h}$ (the synthesis is resumed in Scheme S1 and Figure S1). After this time, the synthesis was naturally cooled to ambient temperature, rinsed (with Milli- $Q$ water) by centrifugation (at $4500 \mathrm{rpm}$ ) five times to remove any residual reactant, and finally the material was dried in an oven at $40{ }^{\circ} \mathrm{C}$.

Fabrication of Electrodes. Initially, the alumina slurries with 1 and $0.05 \mu \mathrm{m}$ mesh were used for the polishing GC disk, subsequently cleaned by consecutive ultrasonication in Milli- $\mathrm{Q}$ water and acetone for $5 \mathrm{~min}$ in each solvent. Finally, the cleaned GC disk was subjected to 10 cycles at a scan speed of $50 \mathrm{mV} \cdot \mathrm{s}^{-1}$ in the potential range of $0.05-1.2 \mathrm{~V}$. The Pt disk was undertaken for 200 cycles at a scan rate of $900 \mathrm{mV} \cdot \mathrm{s}^{-1}$ in the potential range of $0.05-1.2 \mathrm{~V}$. The $\mathrm{N}_{2}$-saturated $0.5 \mathrm{M} \mathrm{H}_{2} \mathrm{SO}_{4}$ was changed several times as required to make sure a clean surface of both GC and Pt electrodes. The carbon paper HCP030N and carbon graphite plate were cleaned by ultrasonication in several Milli- $Q$ water and followed by two cycles at a scan speed of $50 \mathrm{mV} \cdot \mathrm{s}^{-1}$ in a potential window of $0.05-1.2 \mathrm{~V}$ at $\mathrm{N}_{2}$-saturated $0.5 \mathrm{M}$ 
$\mathrm{H}_{2} \mathrm{SO}_{4}$ solution. The catalyst inks were prepared by sonication of 0.5 mg of different catalysts $\left(\beta-\mathrm{Ni}_{2} \mathrm{P}_{2} \mathrm{O}_{7}, \mathrm{Ni}_{3}\left(\mathrm{PO}_{4}\right)_{2}, \mathrm{Ni}_{3}\left(\mathrm{PO}_{4}\right)_{2}{ }^{\prime}, \beta\right.$ $\mathrm{Ni}_{2} \mathrm{P}_{2} \mathrm{O}_{7} / \mathrm{Pt}, \mathrm{Ni}_{3}\left(\mathrm{PO}_{4}\right)_{2} / \mathrm{Pt}, \mathrm{Ni}_{3}\left(\mathrm{PO}_{4}\right)_{2}{ }^{\prime} / \mathrm{Pt}$, or Vulcan$\left./ \mathrm{Pt}\right)$ at $1 \mathrm{~mL}$ of Milli-Q water during at least $1 \mathrm{~h}$. Additionally, a catalyst ink was prepared by sonication of $0.15 \mathrm{mg}$ of Pt NPs at $10 \mathrm{~mL}$ of Milli-Q water during at least $1 \mathrm{~h}$. A homogeneous thin film was consequently produced by dripping $16 \mu \mathrm{L}$ of an aqueous solution of $\underline{\beta}-\mathrm{Ni}_{2} \mathrm{P}_{2} \mathrm{O}_{7}$, $\mathrm{Ni}_{3}\left(\mathrm{PO}_{4}\right)_{2}, \mathrm{Ni}_{3}\left(\mathrm{PO}_{4}\right)_{2}^{\prime}, \beta-\mathrm{Ni}_{2} \mathrm{P}_{2} \mathrm{O}_{7} / \mathrm{Pt}, \mathrm{Ni}_{3}\left(\mathrm{PO}_{4}\right)_{2} / \mathrm{Pt}, \mathrm{Ni}_{3}\left(\mathrm{PO}_{4}\right)_{2}^{\prime} / \mathrm{Pt}$, Vulcan/Pt at $0.5 \mathrm{mg} \cdot \mathrm{mL}^{-1}$ (loading: $40 \mu \mathrm{g} \cdot \mathrm{cm}^{-2}$ ) or Pt NPs at 0.015 $\mathrm{mg} \cdot \mathrm{mL}^{-1}$ (loading: $1.2 \mu \mathrm{g} \cdot \mathrm{cm}^{-2}$ ) onto the GC disk surface and allowing it to dry at ambient temperature. The fabricated electrodes were then connected in a three electrode electrochemical cell setup containing a $0.5 \mathrm{M} \mathrm{H}_{2} \mathrm{SO}_{4}$ solution saturated with $\mathrm{N}_{2}$ or $\mathrm{H}_{2}$ (both obtained from White Martins with 5.0 purity).

Apparatuses and Measurements. The structural crystalline phase identification of the developed $\beta-\mathrm{Ni}_{2} \mathrm{P}_{2} \mathrm{O}_{7}, \mathrm{Ni}_{3}\left(\mathrm{PO}_{4}\right)_{2}$, $\mathrm{Ni}_{3}\left(\mathrm{PO}_{4}\right)_{2}{ }^{\prime}$, and $\beta-\mathrm{Ni}_{2} \mathrm{P}_{2} \mathrm{O}_{7} / \mathrm{Pt}$ samples $(15-30 \mathrm{mg})$ was recorded by powder X-ray diffraction (XRD) technique via a Siemens D5000, Diffrac Plus XRD Commander, X-ray diffractometer with $\mathrm{Cu} \mathrm{K} \alpha$ radiation $(\lambda=0.154 \mathrm{~nm})$ at a scan rate of $0.01^{\circ} \cdot \mathrm{s}^{-1}$. The structural morphology of the synthesized samples was inspected by field emission scanning electron microscopy (FE-SEM) with an FEI Quanta 250 microscope system.

$\beta-\mathrm{Ni}_{2} \mathrm{P}_{2} \mathrm{O}_{7}, \beta-\mathrm{Ni}_{2} \mathrm{P}_{2} \mathrm{O}_{7} / \mathrm{Pt}$, and $\beta-\mathrm{Ni}_{2} \mathrm{P}_{2} \mathrm{O}_{7} / \mathrm{Pt}$ after the 12th day structures were characterized by transmission electron microscopy (TEM), performed on a JEOL JEM2100 $\mathrm{LaB}_{6}$ apparatus operating at $200 \mathrm{kV}$. For this, diluted $\beta-\mathrm{Ni}_{2} \mathrm{P}_{2} \mathrm{O}_{7}, \beta-\mathrm{Ni}_{2} \mathrm{P}_{2} \mathrm{O}_{7} / \mathrm{Pt}$, and $\beta-\mathrm{Ni}_{2} \mathrm{P}_{2} \mathrm{O}_{7} / \mathrm{Pt}$ after the 12th day aqueous reaction solutions were dropped onto carbon films embedded on a lacey carbon film on a 400-mesh copper grid (Ted Pella).

The electron energy loss spectroscopy (EELS) experiments were performed using a JEOL JEM 2100F microscope (operated at 200 $\mathrm{kV}$ ) equipped with a GATAN Imaging Filtering system (EELS-GIF Tridium). All EEL spectra were collected with a dispersion of $0.3 \mathrm{eV} /$ ch, with an aperture label of $2.0 \mathrm{~mm}$ under an STEM illumination mode. The software Digital Micrograph was used to subtract the background (through the power law method).

XPS analysis was performed with an Omicron surface analysis station equipped with an SPHERA hemispherical analyzer and a DAR $400 \mathrm{Al} \mathrm{K} \alpha(1486.7 \mathrm{eV}) \mathrm{X}$-ray source. The chamber was evacuated to $1 \times 10^{-8}$ mbar during analysis. Pass energies were 50 and $10 \mathrm{eV}$ for survey- and high-resolution spectra, respectively. The Voigt-type function with Gaussian (70\%) and Lorentzian (30\%) was used for the deconvolution of XPS spectra.

ICP-OES was performed to identify the content of $\mathrm{Pt}$ in $\beta$ $\mathrm{Ni}_{2} \mathrm{P}_{2} \mathrm{O}_{7} / \mathrm{Pt}$ using Thermo Fisher Scientific iCAP 6300 Duo equipment with the operating conditions of RF power being 1250 $\mathrm{W}$, sample flow was $0.45 \mathrm{~L} \cdot \mathrm{min}^{-1}$, plasma gas flow rate was $12 \mathrm{~L}$. $\min ^{-1}$, an integration time of $5 \mathrm{~s}$, a stabilization time of $20 \mathrm{~s}$, nebulization pressure was $20 \mathrm{psi}$, and axial view mode, $\lambda=214.423$ $\mathrm{nm}$ to $\mathrm{Pt}$ ). Further, more detail on the Pt ICP-OES identification can be seen in Supporting Information.

All electrochemical techniques such as cyclic voltammogram (CV), chronoamperometry, hydrodynamic $\mathrm{CV}$, and hydrodynamic linear potential scan (HLS) were measured by an AFP2 WaveDriver 20 bipotentiostat-galvanostat equipped with an AFMSRCE modulated speed rotator (Pine Research Instrumentation).

A PGSTAT128N potentiostat-galvanostat (Autolab) equipped with a FRA2.X module was utilized for EIS measurements, which was carried out at a fixed OCP value of around $0.55 \mathrm{~V}$ (on average) or at $-10,-20$, and $-50 \mathrm{mV}$ in $0.5 \mathrm{M} \mathrm{H}_{2} \mathrm{SO}_{4}$, with potential perturbation of $10 \mathrm{mV}$ (rms) within a frequency range of $10 \mathrm{mHz}$ to $100 \mathrm{kHz}$. Concern was taken to make sure that AC impedance output data matched to the interfaces being inspected at high frequencies, as depicted in ref 33. Every HLS curve was adjusted for ohmic drop resistance estimated and determined from the fitted intercept at high frequency of EIS. Ohmic drop resistance estimated in $0.5 \mathrm{M} \mathrm{H}_{2} \mathrm{SO}_{4}$ was $6 \Omega$ on average (Figure S2).

Normalization of HLS curves was based on electrochemically active surface area (ECSA) and actual electrode geometric area values. The
ECSA values were obtained by stripping of $\mathrm{H}_{\text {upd }}\left(50 \mathrm{mV} \cdot \mathrm{s}^{-1}\right)$ and $\mathrm{Cu}_{\text {upd }}{ }^{34,35}$ Charge density was taken as $210 \mu \mathrm{C} \cdot \mathrm{cm}^{-236}$ for bare Pt and Vulcan/Pt/GC-modified electrode surfaces and $420 \mu \mathrm{C} \cdot \mathrm{cm}^{-2}$ for the $\beta-\mathrm{Ni}_{2} \mathrm{P}_{2} \mathrm{O}_{7} / \mathrm{Pt}$ surface. $\mathrm{Cu}_{\text {upd }}$ stripping was carried out in $1 \mathrm{mM}$ $\mathrm{CuSO}_{4}$ in $0.5 \mathrm{M} \mathrm{H}_{2} \mathrm{SO}_{4}$ solution. The potential at the $\beta-\mathrm{Ni}_{2} \mathrm{P}_{2} \mathrm{O}_{7} / \mathrm{Pt} /$ GC electrode was kept at $1.0 \mathrm{~V}$ during $200 \mathrm{~s}$, followed by a $900 \mathrm{~s}$ step at $0.4 \mathrm{~V}$, and consequently by an HLS from 0.4 to $1.0 \mathrm{~V}$ at $5 \mathrm{mV} \cdot \mathrm{s}^{-1}$ and $600 \mathrm{rpm}$.

The ECSA was also estimated from the electrochemical doublelayer capacitance $\left(C_{\mathrm{dl}}\right)$ to $\beta-\mathrm{Ni}_{2} \mathrm{P}_{2} \mathrm{O}_{7}$ and $\beta-\mathrm{Ni}_{2} \mathrm{P}_{2} \mathrm{O}_{7} / \mathrm{Pt}$ by collecting CVs from 5 to $800 \mathrm{mV} \cdot \mathrm{s}^{-1}$ in a potential window of $0.1 \mathrm{~V}$ centered at the OCP (measured currents in this non-Faradaic potential region might be because of the double-layer charging). ${ }^{37}$ During these $\mathrm{CV}$ measurements, the working electrode was held at each potential vertex for $10 \mathrm{~s}$ before beginning the next sweep. ${ }^{37}$ The double-layer charging current is equal to the product of the potential scan rate, $\nu$, and the $\mathrm{C}_{\mathrm{d} b}{ }^{37}$ expressed by eq 1 :

$$
\Delta I / 2=\left(I_{(+)}-I_{(-)}\right) / 2=\nu \times C_{\mathrm{dl}}
$$

The ECSA based on the $C_{\mathrm{dl}}$ was calculated according to eq 2

$$
\mathrm{ECSA}=C_{\mathrm{dl}} / C_{\mathrm{s}}
$$

where $C_{\mathrm{s}}$ is the specific capacitance, here, we used the capacitance of an atomically smooth planar surface of the material per unit area under identical electrolyte conditions with a value of $0.035 \mathrm{mF}$. $\mathrm{cm}^{-2} \cdot 37$

\section{RESULTS AND DISCUSSION}

XRD Studies. The XRD patterns of the produced $\beta$ $\mathrm{Ni}_{2} \mathrm{P}_{2} \mathrm{O}_{7} / \mathrm{Pt}, \beta-\mathrm{Ni}_{2} \mathrm{P}_{2} \mathrm{O}_{7}, \mathrm{Ni}_{3}\left(\mathrm{PO}_{4}\right)_{2}$, and $\mathrm{Ni}_{3}\left(\mathrm{PO}_{4}\right)_{2}^{\prime}$ materials are depicted in Figure 1 . The XRD pattern of synthesized $\beta$ -

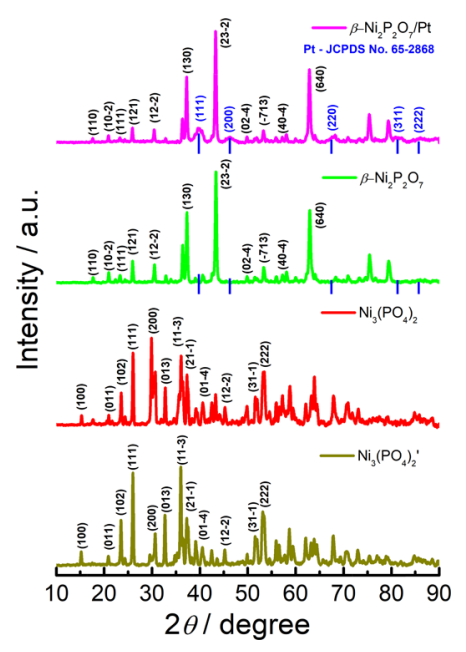

Figure 1. XRD spectra of $\beta-\mathrm{Ni}_{2} \mathrm{P}_{2} \mathrm{O}_{7} / \mathrm{Pt}, \beta-\mathrm{Ni}_{2} \mathrm{P}_{2} \mathrm{O}_{7}, \mathrm{Ni}_{3}\left(\mathrm{PO}_{4}\right)_{2}$, and $\mathrm{Ni}_{3}\left(\mathrm{PO}_{4}\right)_{2}^{\prime}$ samples.

$\mathrm{Ni}_{2} \mathrm{P}_{2} \mathrm{O}_{7}$ by a simple precipitation method is in good agreement with the equivalent (110), (10-2), (111), (121), $(12-2),(130),(23-2),(02-4),(-713),(40-4)$, and (640) diffraction planes of monoclinic $\mathrm{Ni}_{2} \mathrm{P}_{2} \mathrm{O}_{7}$ (JCPDS No. 741604). The $\mathrm{XRD}$ pattern for $\beta-\mathrm{Ni}_{2} \mathrm{P}_{2} \mathrm{O}_{7} / \mathrm{Pt}$ shows the diffraction peaks corresponding to the $\beta-\mathrm{Ni}_{2} \mathrm{P}_{2} \mathrm{O}_{7}$ sample, in addition to the diffraction peaks for $\mathrm{Pt}(111),(200),(220)$, (311), and (222) planes at $2 \theta=39.7,46.3,67.8,82.0$ and $85.6^{\circ}$ (more evident: 39.7 and $46.3^{\circ}$; due to addition of the very small amount of $\mathrm{Pt}(\sim 3 \mathrm{wt} \%)$ in the sample), respectively, identified for $\mathrm{Pt}$ (JCPDS No. 65-2868). The diffraction peaks of the $\mathrm{Ni}_{3}\left(\mathrm{PO}_{4}\right)_{2}$ synthesized by precipitation process revealed several peaks and the exhibited $(h k l)$ 


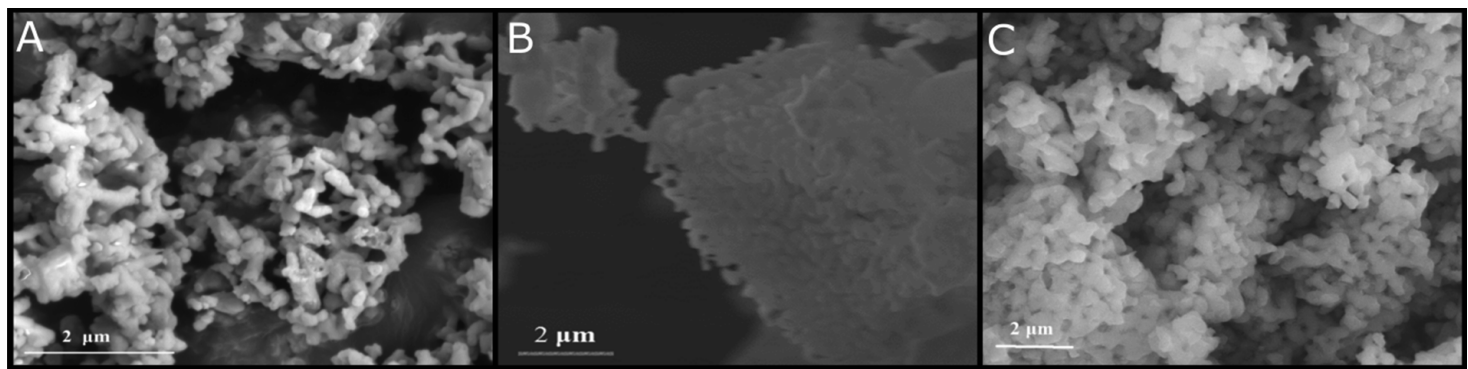

Figure 2. FE-SEM morphology of (A) $\beta-\mathrm{Ni}_{2} \mathrm{P}_{2} \mathrm{O}_{7},(\mathrm{~B}) \mathrm{Ni}_{3}\left(\mathrm{PO}_{4}\right)_{2}$, and $(\mathrm{C}) \mathrm{Ni}_{3}\left(\mathrm{PO}_{4}\right)_{2}^{\prime}$ samples.

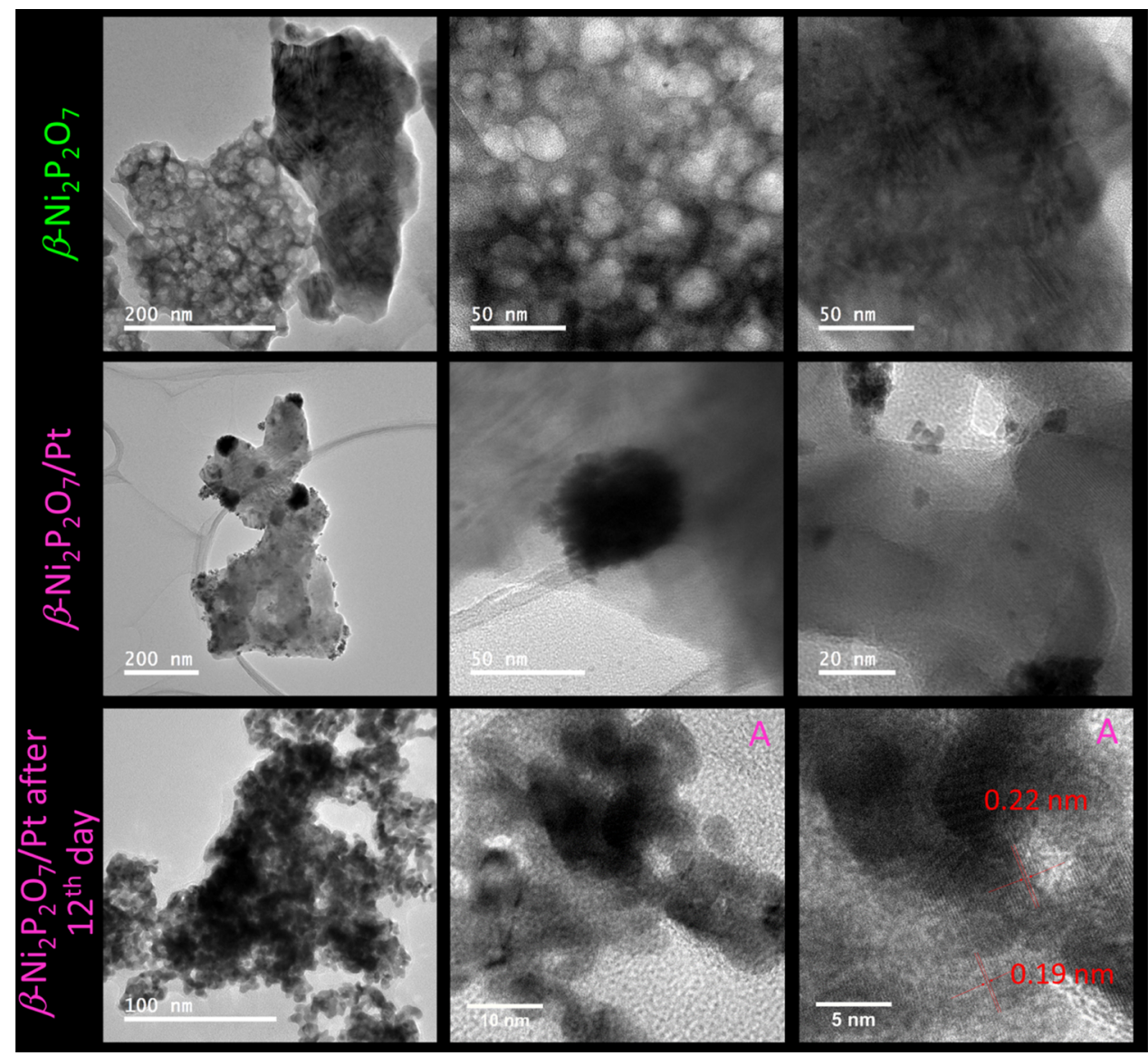

Figure 3. TEM images of $\beta-\mathrm{Ni}_{2} \mathrm{P}_{2} \mathrm{O}_{7}, \beta-\mathrm{Ni}_{2} \mathrm{P}_{2} \mathrm{O}_{7} / \mathrm{Pt}$, and $\beta-\mathrm{Ni}_{2} \mathrm{P}_{2} \mathrm{O}_{7} / \mathrm{Pt}$ after the 12th day samples, and HR-TEM images of $(\mathrm{A}) \beta$-Ni $\mathrm{P}_{2} \mathrm{O}_{7} / \mathrm{Pt}$ after the 12th day sample.

diffraction planes (100), (011), (102), (111), (200), (013), (11-3), (21-1), (01-4), (12-2), (31-1), and (222). They are indexed according to the information of monoclinic crystal structure of $\mathrm{Ni}_{3}\left(\mathrm{PO}_{4}\right)_{2}$ (JCPDS No. 15-3160). The diffraction pattern of $\mathrm{Ni}_{3}\left(\mathrm{PO}_{4}\right)_{2}^{\prime}$ synthesized by solution combustion process illustrates that the diffraction pattern of $\mathrm{Ni}_{3}\left(\mathrm{PO}_{4}\right)_{2}$ synthesized by precipitation route is not changed by the synthetic route. However, it could be noticed that the small changes in diffraction angles and peak intensity, which might be due to the various synthetic conditions on $\mathrm{Ni}_{3}\left(\mathrm{PO}_{4}\right)_{2}$ generating substantial expansion and contraction of the lattice constants.

The above XRD investigation confirms the formation of $\beta$ $\mathrm{Ni}_{2} \mathrm{P}_{2} \mathrm{O}_{7}, \beta-\mathrm{Ni}_{2} \mathrm{P}_{2} \mathrm{O}_{7} / \mathrm{Pt}, \mathrm{Ni}_{3}\left(\mathrm{PO}_{4}\right)_{2}$, and $\mathrm{Ni}_{3}\left(\mathrm{PO}_{4}\right)_{2}^{\prime}$ materials, and the resultant average crystalline size calculated using Scherrer's equation ${ }^{38-40}$ was about $9.1,8.9,36.6$, and $41.8 \mathrm{~nm}$, respectively. The difference in the average crystalline size of
$\mathrm{Ni}_{3}\left(\mathrm{PO}_{4}\right)_{2}$ and $\mathrm{Ni}_{3}\left(\mathrm{PO}_{4}\right)_{2}{ }^{\prime}$ by changing of synthetic conditions and the biggest change in crystalline size to $\beta-\mathrm{Ni}_{2} \mathrm{P}_{2} \mathrm{O}_{7}$ in relation to $\mathrm{Ni}_{3}\left(\mathrm{PO}_{4}\right)_{2}$ and $\mathrm{Ni}_{3}\left(\mathrm{PO}_{4}\right)_{2}{ }^{\prime}$ could be noticed, in addition to the decreased crystalline size to $\beta-\mathrm{Ni}_{2} \mathrm{P}_{2} \mathrm{O}_{7} / \mathrm{Pt}$ in relation to $\beta-\mathrm{Ni}_{2} \mathrm{P}_{2} \mathrm{O}_{7}$. The smaller crystalline size may be likely to show an enhanced electrocatalytic active sites, which may also lead to show an improved electrocatalytic performance.

Morphology Studies. The shape and structural morphologies of the synthesized $\beta-\mathrm{Ni}_{2} \mathrm{P}_{2} \mathrm{O}_{7}, \mathrm{Ni}_{3}\left(\mathrm{PO}_{4}\right)_{2}$, and $\mathrm{Ni}_{3}\left(\mathrm{PO}_{4}\right)_{2}{ }^{\prime}$ samples were analyzed by FE-SEM, and the resulting pictures are exhibited in Figure 2. The FE-SEM morphology of the $\beta-\mathrm{Ni}_{2} \mathrm{P}_{2} \mathrm{O}_{7}$ sample shows an aggregated granular-like ${ }^{32}$ particles (Figure 2A). However, the FE-SEM image of $\mathrm{Ni}_{3}\left(\mathrm{PO}_{4}\right)_{2}$ shows a micrometer size granular-like surface structure made by nanoflakes (Figure 2B). The structural morphology of $\mathrm{Ni}_{3}\left(\mathrm{PO}_{4}\right)_{2}{ }^{\prime}$ synthesized by precipitation process exhibited the hierarchical granular-like 
morphology (Figure 2C). It was observed that the structural morphology of $\mathrm{Ni}_{3}\left(\mathrm{PO}_{4}\right)_{2}$ sample is tightly packed granularlike particles, which are probable to be an additional benefit for the transport of electron. ${ }^{41,42}$ However, the particles such as the $\beta-\mathrm{Ni}_{2} \mathrm{P}_{2} \mathrm{O}_{7}$ sample may be better arranged at a GC surface.

Further, the structures of $\beta-\mathrm{Ni}_{2} \mathrm{P}_{2} \mathrm{O}_{7}, \beta-\mathrm{Ni}_{2} \mathrm{P}_{2} \mathrm{O}_{7} / \mathrm{Pt}$, and $\mathrm{Pt}$ NP samples were investigated by TEM, HR-TEM, electron diffraction pattern, HAADF-STEM, and EDX mapping images; the equivalent pictures are shown in Figures 3 and 4 and
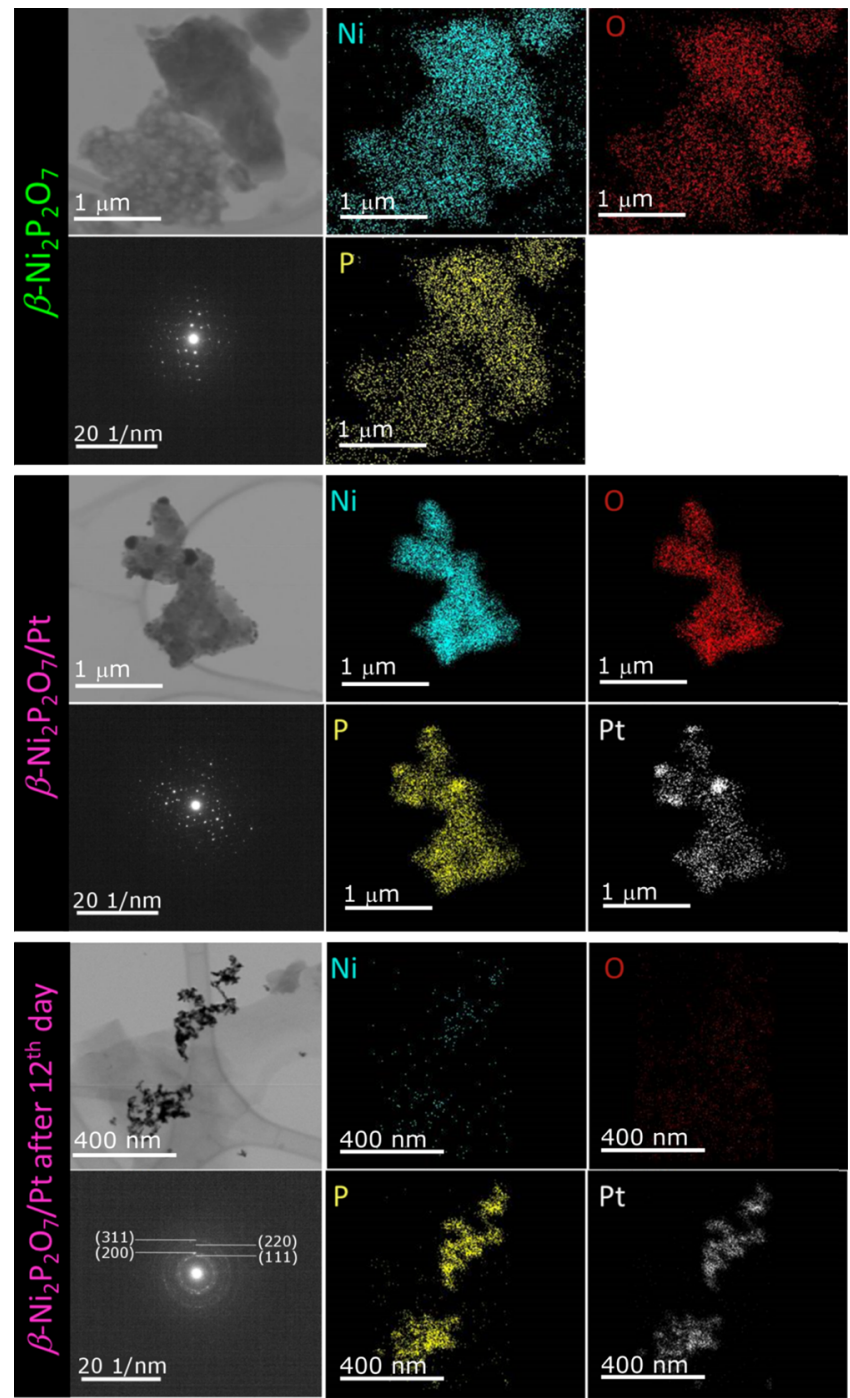

Figure 4. HAADF-STEM, EDX mapping, and electron diffraction pattern images of $\beta-\mathrm{Ni}_{2} \mathrm{P}_{2} \mathrm{O}_{7}, \beta-\mathrm{Ni}_{2} \mathrm{P}_{2} \mathrm{O}_{7} / \mathrm{Pt}$, and $\beta-\mathrm{Ni}_{2} \mathrm{P}_{2} \mathrm{O}_{7} / \mathrm{Pt}$ after the 12 th day samples.

Figures $\mathrm{S} 3$ and $\mathrm{S} 4$. The TEM images of $\beta-\mathrm{Ni}_{2} \mathrm{P}_{2} \mathrm{O}_{7}$ (Figure 3 and Figure S3) show rounded whitish structures with different sizes as well as darkened structures such as plates ${ }^{32}$ with a distance of fringes of $0.97 \mathrm{~nm} . \beta-\mathrm{Ni}_{2} \mathrm{P}_{2} \mathrm{O}_{7} / \mathrm{Pt}$ has visible, large Pt NPs directly or not directly supported at the $\beta-\mathrm{Ni}_{2} \mathrm{P}_{2} \mathrm{O}_{7}$ structure (Figure 3 and Figure S3) as well as small Pt NPs also appearing to be imbibed into the $\beta-\mathrm{Ni}_{2} \mathrm{P}_{2} \mathrm{O}_{7}$ structure, presenting a mean Pt particle size distribution (PSD) of 9.7 $\pm 4.6 \mathrm{~nm}$ (Figure S3). The distance of fringes is now $0.67 \mathrm{~nm}$. These distances of fringes are close to distances present in the unitary cell of $\beta-\mathrm{Ni}_{2} \mathrm{P}_{2} \mathrm{O}_{7}$ structure (Scheme S1). TEM and HR-TEM images of Pt NPs synthesized in the absence of $\beta$ -
$\mathrm{Ni}_{2} \mathrm{P}_{2} \mathrm{O}_{7}$ are shown in Figure S4, which can be seen larger Pt NPs such as the large Pt NPs directly or not directly supported at $\beta-\mathrm{Ni}_{2} \mathrm{P}_{2} \mathrm{O}_{7}$ structure (Figure 3 and Figure S3), with $\mathrm{Pt}$ dendritic structures ${ }^{43-47}$ (Figure S4). The visible distance of fringes appeared now as 0.19 to $0.22 \mathrm{~nm}$ (HR-TEM image A at Figure S4 to Pt NPs).

The EDX mapping (Figure 4) to the $\beta-\mathrm{Ni}_{2} \mathrm{P}_{2} \mathrm{O}_{7}$ sample shows clearly the presence of $\mathrm{Ni}, \mathrm{O}$, and $\mathrm{P}$, equally distributed $^{32}$ and very close to each other in the rounded whitish and plate structures of $\beta-\mathrm{Ni}_{2} \mathrm{P}_{2} \mathrm{O}_{7}$. The diffraction pattern is well visible to $\beta-\mathrm{Ni}_{2} \mathrm{P}_{2} \mathrm{O}_{7}$ sample (Figure 4). To the $\beta-\mathrm{Ni}_{2} \mathrm{P}_{2} \mathrm{O}_{7} / \mathrm{Pt}$ sample, the EDX mapping (Figure 4) to $\mathrm{Ni}, \mathrm{O}$, and $\mathrm{P}$ is similar to the $\beta-\mathrm{Ni}_{2} \mathrm{P}_{2} \mathrm{O}_{7}$ sample with exception to the detection of $\mathrm{Pt}$ very well distributed to $\beta-\mathrm{Ni}_{2} \mathrm{P}_{2} \mathrm{O}_{7}$ and closer to the $\mathrm{P}$ atoms, which reinforces the occurrence of small Pt NPs imbibed into the $\beta-\mathrm{Ni}_{2} \mathrm{P}_{2} \mathrm{O}_{7}$ structure (see high intensity of detected $\mathrm{Pt}$ to larger $\mathrm{Pt} \mathrm{NPs}$ at $\beta-\mathrm{Ni}_{2} \mathrm{P}_{2} \mathrm{O}_{7} / \mathrm{Pt}$ sample in Figure 4). The diffraction pattern is also well visible to $\beta-\mathrm{Ni}_{2} \mathrm{P}_{2} \mathrm{O}_{7} / \mathrm{Pt}$ sample (Figure 4); however, it appears different when compared with the diffraction pattern to $\beta-\mathrm{Ni}_{2} \mathrm{P}_{2} \mathrm{O}_{7}$, as previous detected to different distance of fringes to $\beta$ $\mathrm{Ni}_{2} \mathrm{P}_{2} \mathrm{O}_{7}$ and $\beta-\mathrm{Ni}_{2} \mathrm{P}_{2} \mathrm{O}_{7} / \mathrm{Pt}$ (TEM images at Figure 3). The diffraction pattern to $\mathrm{Pt}$ NP samples (Figure S4) is consistent with the spots in distances matching to face-centered cubic (fcc) crystalline phase of Pt with (111), (200), (220), and (311) planes. ${ }^{43-47}$ The low intensity of the spots (Figure S4) is consistent with the $\mathrm{Pt}$ dendritic structures. ${ }^{43-47}$ The $\beta$ $\mathrm{Ni}_{2} \mathrm{P}_{2} \mathrm{O}_{7} / \mathrm{Pt}$ sample (Figure 4) presents not well-defined concentric spot characteristic of Pt NPs (Figure S4), which was not identified at the $\beta-\mathrm{Ni}_{2} \mathrm{P}_{2} \mathrm{O}_{7}$ sample (Figure 4).

EELS Analysis. The $\mathrm{Ni}_{2,3}$ edge electron energy loss nearedge structures (ELNES), core-loss spectra in the EELS, of $\mathrm{Ni}\left(\mathrm{NO}_{3}\right)_{2}$ (standard), $\beta-\mathrm{Ni}_{2} \mathrm{P}_{2} \mathrm{O}_{7}$, and $\beta-\mathrm{Ni}_{2} \mathrm{P}_{2} \mathrm{O}_{7} / \mathrm{Pt}$ are shown in Figure 5A. Spin-orbit coupling to Ni-2p orbitals emerges as doubly degenerated $2 \mathrm{p}_{1 / 2}$ and quadruple $2 \mathrm{p}_{3 / 2}{ }^{48}$ The main transitions should be from Ni-2p levels to Ni-3d. ${ }^{48}$ Thereby, the $\mathrm{Ni}_{2,3}$ edge ELNES for different samples (Figure 5A) comprises two major peaks related for transitions from $2 \mathrm{p}_{1 / 2}\left(\mathrm{~L}_{2}\right.$ edge around $\left.872 \mathrm{eV}\right)$ and from $2 \mathrm{p}_{3 / 2}$ orbitals $\left(\mathrm{L}_{3}\right.$ edge around $855 \mathrm{eV}$ ), in agreement with results shown for $\mathrm{NiO}{ }^{48}$ For $\mathrm{Ni}\left(\mathrm{NO}_{3}\right)_{2}$ (standard), the experimental $\mathrm{L}_{3}$ peak at $855 \mathrm{eV}$ was not completely sharp in addition to present a shoulder toward lower energy, and the $\mathrm{L}_{2}$ peak at $871.5 \mathrm{eV}$ was trapezoidal shaped. For $\beta-\mathrm{Ni}_{2} \mathrm{P}_{2} \mathrm{O}_{7}$, the $\mathrm{L}_{3}$ peak at $855 \mathrm{eV}$ was totally sharp in addition to present a shoulder toward higher energy, presenting also a triangular-shaped $\mathrm{L}_{2}$ peak at $872 \mathrm{eV}$. For $\beta-\mathrm{Ni}_{2} \mathrm{P}_{2} \mathrm{O}_{7} / \mathrm{Pt}$, the $\mathrm{L}_{3}$ peak at $855 \mathrm{eV}$ was broad, presenting also a triangular-shaped $\mathrm{L}_{2}$ peak at $872 \mathrm{eV}$. The profile of the $\mathrm{Ni} \mathrm{L}_{2,3}$ edge ELNES firmly reflects the nearby electronic structure of the $\mathrm{Ni}$ atom, for instance, spin state, oxidation, and coordination number. ${ }^{48}$ The distinctive features of the $\mathrm{Ni} \mathrm{L}_{2,3}$ edge ELNES, as a result, propose that the $\mathrm{Ni}$ atoms are in a different electronic structure in $\mathrm{Ni}\left(\mathrm{NO}_{3}\right)_{2}$ (standard), $\beta$ $\mathrm{Ni}_{2} \mathrm{P}_{2} \mathrm{O}_{7}$, and $\beta-\mathrm{Ni}_{2} \mathrm{P}_{2} \mathrm{O}_{7} / \mathrm{Pt}$.

The $\mathrm{O}-\mathrm{K}$ edge ELNES mostly matched to electron transitions from $\mathrm{O} 1 \mathrm{~s}$ core level to unoccupied $\mathrm{O} 2 \mathrm{p}$ orbitals. ${ }^{48}$ The ELNES of $\mathrm{Ni}\left(\mathrm{NO}_{3}\right)_{2}$ (standard) (Figure $5 \mathrm{~B}$ ) consists of four major peaks at 525, 528, 537.7 (with shoulders at low and high energy, the main peak), and $562 \mathrm{eV}$. The ELNES of $\beta$ $\mathrm{Ni}_{2} \mathrm{P}_{2} \mathrm{O}_{7}$ (Figure 5B) consists of only two major peaks. The first peak is coincident with the third (including the shoulders) and the fourth peaks of $\mathrm{Ni}\left(\mathrm{NO}_{3}\right)_{2}$ (standard) at 537.3 and $563.5 \mathrm{eV}$, respectively, to $\beta-\mathrm{Ni}_{2} \mathrm{P}_{2} \mathrm{O}_{7}$. The $\mathrm{O}-\mathrm{K}$ edge ELNES 

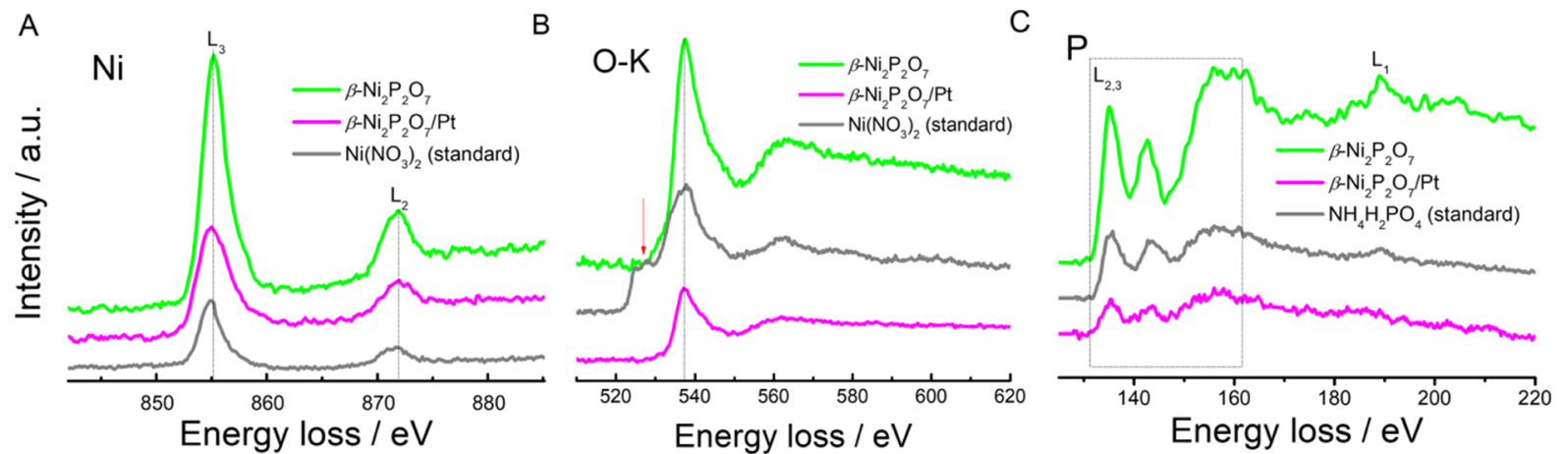

Figure 5. EELS spectra of the (A) Ni- $\mathrm{L}_{2,3}$ edge, (B) O-K edge, and (C) $\mathrm{P}-\mathrm{L}$ edge of the $\beta-\mathrm{Ni}_{2} \mathrm{P}_{2} \mathrm{O}_{7} / \mathrm{Pt}, \beta-\mathrm{Ni}_{2} \mathrm{P}_{2} \mathrm{O}_{7}, \mathrm{Ni}\left(\mathrm{NO}_{3}\right)_{2}$, and $\mathrm{NH}_{4} \mathrm{H}_{2} \mathrm{PO}$.
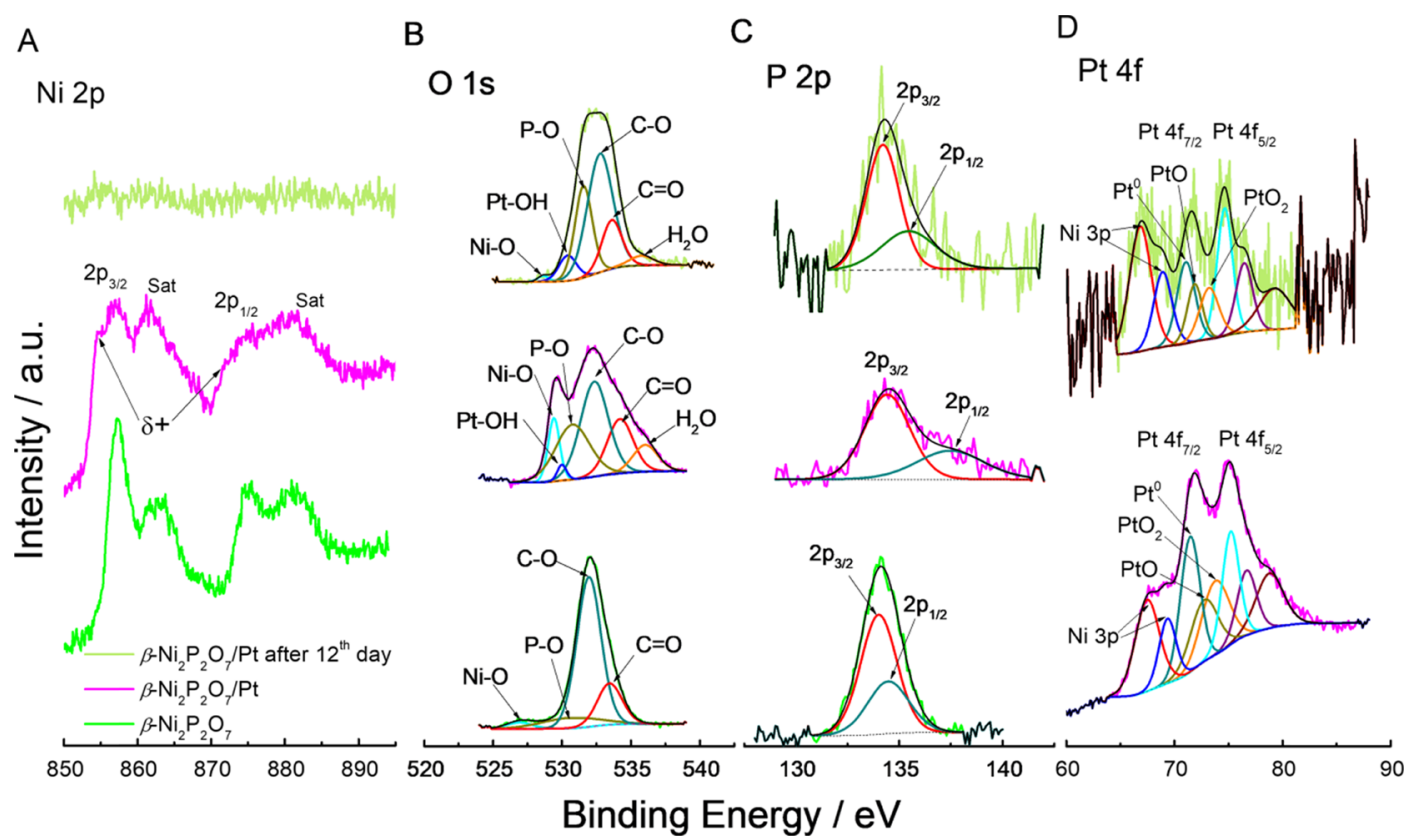

Figure 6. High-resolution (A) Ni 2p, (B) O 1s, (C) P 2p, and (D) Pt 4f XPS spectra of $\beta-\mathrm{Ni}_{2} \mathrm{P}_{2} \mathrm{O}_{7}, \beta-\mathrm{Ni}_{2} \mathrm{P}_{2} \mathrm{O}_{7} / \mathrm{Pt}$, and $\beta$ - $\mathrm{Ni}_{2} \mathrm{P}_{2} \mathrm{O}_{7} / \mathrm{Pt}$ after the 12 th day.

of $\beta-\mathrm{Ni}_{2} \mathrm{P}_{2} \mathrm{O}_{7} / \mathrm{Pt}$ in Figure $5 \mathrm{~B}$ contains of two major peaks at 537.3 and $562 \mathrm{eV}$. For the last two materials, the first peak is located at higher energy than that for $\mathrm{Ni}\left(\mathrm{NO}_{3}\right)_{2}$ (standard). The electron transitions corresponding to the main peak to different materials may take place via covalent bonding between the $\mathrm{O} 2 \mathrm{p}$ and $\mathrm{Ni} 3 \mathrm{~d}$ orbitals, ${ }^{48}$ meaning that the disappearance of the peaks at 525 and $528 \mathrm{eV}$ from $\mathrm{Ni}\left(\mathrm{NO}_{3}\right)_{2}$ (standard) in relation to $\beta-\mathrm{Ni}_{2} \mathrm{P}_{2} \mathrm{O}_{7}$, and the disappearance of the shoulders from the peak at $537.3 \mathrm{eV}$ to $\beta-\mathrm{Ni}_{2} \mathrm{P}_{2} \mathrm{O}_{7} / \mathrm{Pt}$ in relation to $\beta-\mathrm{Ni}_{2} \mathrm{P}_{2} \mathrm{O}_{7}$ indicates that the covalent bonding becomes stronger in the order of $\mathrm{Ni}\left(\mathrm{NO}_{3}\right)_{2}$ (standard), $\beta$ $\mathrm{Ni}_{2} \mathrm{P}_{2} \mathrm{O}_{7}$, and $\beta-\mathrm{Ni}_{2} \mathrm{P}_{2} \mathrm{O}_{7} / \mathrm{Pt}$. This is in agreement with distance of fringes decreased from 0.97 to $0.67 \mathrm{~nm}$ to $\beta-\mathrm{Ni}_{2} \mathrm{P}_{2} \mathrm{O}_{7}$ and $\beta$ $\mathrm{Ni}_{2} \mathrm{P}_{2} \mathrm{O}_{7} / \mathrm{Pt}$, respectively (TEM images at Figure 3)

The $\mathrm{P}-\mathrm{L}_{2,3}$ and $\mathrm{L}_{1}$ edge ELNES correspond to electron transition from $\mathrm{P} 2 \mathrm{p}$ core level to both $\mathrm{s}-(l=0)$ and $\mathrm{d}$ character $(l=2)$ final states ${ }^{49}$ and $\mathrm{P} 2$ s core level to p state $(l=$ 1), respectively. ${ }^{49}$ The ELNES of $\mathrm{NH}_{4} \mathrm{H}_{2} \mathrm{PO}_{4}$ (standard) (Figure 5C) consists of four major peaks at 135.5, 143.4, 156 $\left(\mathrm{P} \mathrm{L}_{2,3}\right)$, and $189.5\left(\mathrm{P} \mathrm{L}_{1}\right)$ eV. The ELNES of $\beta-\mathrm{Ni}_{2} \mathrm{P}_{2} \mathrm{O}_{7}$ (Figure 5C) consists of similar peaks at 135.2, 142.7, 159.5 (trapezoidal shaped) $\left(\mathrm{P} \mathrm{L}_{2,3}\right)$, and $189\left(\mathrm{P} \mathrm{L}_{1}\right) \mathrm{eV}$. The ELNES of $\beta-\mathrm{Ni}_{2} \mathrm{P}_{2} \mathrm{O}_{7} / \mathrm{Pt}$ in Figure $5 \mathrm{C}$ consists of peaks at 135.4, 144,
$157 \mathrm{eV}\left(\mathrm{P} \mathrm{L}_{2,3}\right)$, and not identifiable $\mathrm{P}_{1}$ peak. The peak around $136 \mathrm{eV}$ is attributed to $\mathrm{P}_{x} \mathrm{O}_{y}$ species, ${ }^{50,51}$ as well the peaks from 140 to $160 \mathrm{eV}$ (and the peak at $189 \mathrm{eV}$ ). ${ }^{51}$ The presence of $\mathrm{Ni}$ at $\beta-\mathrm{Ni}_{2} \mathrm{P}_{2} \mathrm{O}_{7}$ displaced the peaks in ELNES spectrum to low energy in comparison with the ELNES of $\mathrm{NH}_{4} \mathrm{H}_{2} \mathrm{PO}_{4}$ (standard). The presence of $\mathrm{Pt}$ at $\beta-\mathrm{Ni}_{2} \mathrm{P}_{2} \mathrm{O}_{7} / \mathrm{Pt}$ displaced the peaks in ELNES spectrum to high energy in comparison with the ELNES of $\beta-\mathrm{Ni}_{2} \mathrm{P}_{2} \mathrm{O}_{7}$, with not identifiable $\mathrm{P} \mathrm{L}_{1}$ peak to $\beta-\mathrm{Ni}_{2} \mathrm{P}_{2} \mathrm{O}_{7} / \mathrm{Pt}$-most probable due to the few unfilled $\mathrm{p}$ states and their energy distribution is broad than that of the $\mathrm{d}$ states, so the $\mathrm{L}_{1}$ turns invisible. ${ }^{49}$ This observation is corroborated by the presence of Pt NPs close to the $\mathrm{P}$ atoms to $\beta-\mathrm{Ni}_{2} \mathrm{P}_{2} \mathrm{O}_{7} / \mathrm{Pt}$ sample (Figure 4). The slight but perceptible differences in FTIR spectra (Figure S5) are also experimental evidence of the interactions of small amount of $\mathrm{Pt}$ (Pt NPs) present in the $\beta-\mathrm{Ni}_{2} \mathrm{P}_{2} \mathrm{O}_{7} / \mathrm{Pt}$ material, which in turn affect the vibrational modes of the $\mathrm{P}-\mathrm{O}-\mathrm{P}$ groupments (see complementary information in the Supporting Information about FTIR analysis).

XPS Analysis. Figure S6 depicts the XPS spectra of $\beta$ $\mathrm{Ni}_{2} \mathrm{P}_{2} \mathrm{O}_{7}$ and $\beta-\mathrm{Ni}_{2} \mathrm{P}_{2} \mathrm{O}_{7} / \mathrm{Pt}$ where Ni $2 \mathrm{p}, \mathrm{O} 1 \mathrm{~s}, \mathrm{C} 1 \mathrm{~s}, \mathrm{P} 2 \mathrm{~s}, \mathrm{P}$ $2 \mathrm{p}$, and $\mathrm{Ni} 3 \mathrm{p}$, in addition to $\mathrm{Pt} 4 \mathrm{~s}, \mathrm{Pt} 4 \mathrm{~d}$, and $\mathrm{Pt} 4 \mathrm{f}$ ( $\mathrm{Pt}$ peaks to $\left.\beta-\mathrm{Ni}_{2} \mathrm{P}_{2} \mathrm{O}_{7} / \mathrm{Pt}\right)$ peaks are noticeable. Positions and atomic 

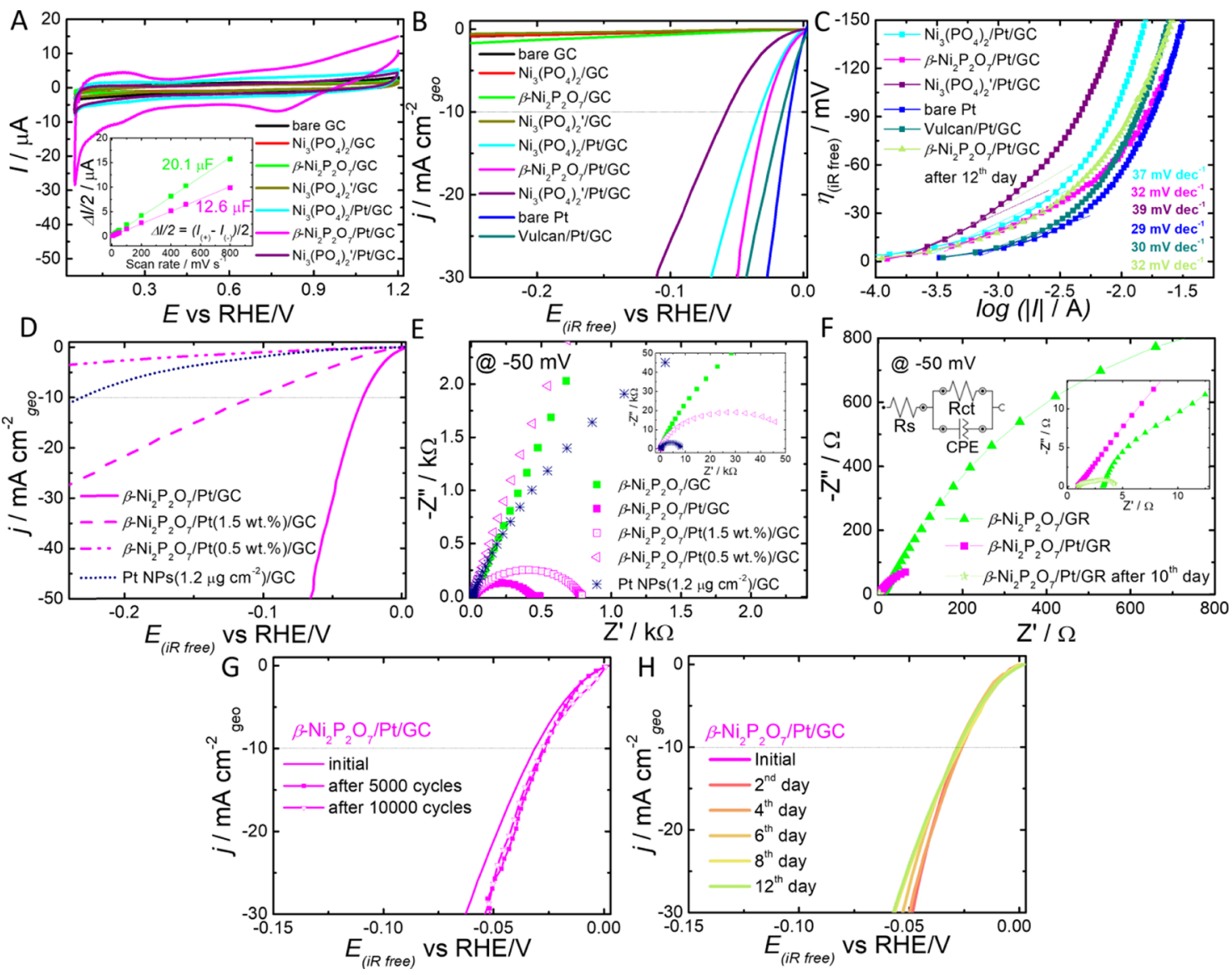

$\mathrm{Z}^{\prime} / \mathrm{k} \Omega$

$Z^{\prime} / \Omega$

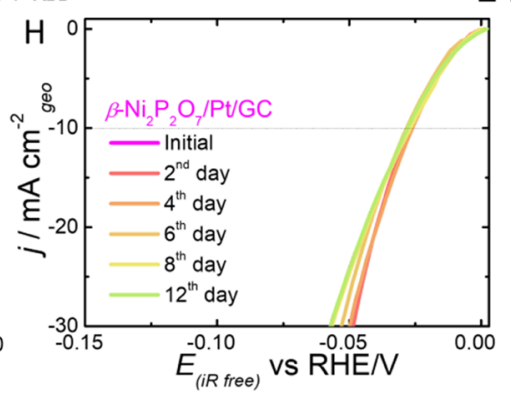

Figure 7. (A) CVs for bare and modified GC electrodes. Potential scan rate: $50 \mathrm{mV} \cdot \mathrm{s}^{-1}$. Potential scan starts at $1.2 \mathrm{~V}$. Inset: $\Delta I / 2 \mathrm{vs} \nu$ for modified GC electrodes. (B) HLSs (corrected for ohmic-drop resistance) recorded with bare Pt and GC and modified GC electrodes. Scans started at 0.0 V. $\omega=1600 \mathrm{rpm}, \nu: 5 \mathrm{mV} \cdot \mathrm{s}^{-1}$. Current densities (currents used from Figure S7C) shown by electrode geometric area. (C) Tafel plots for bare Pt and modified GC electrodes (data from Figure S7C). (D) HLSs (corrected for ohmic-drop resistance) recorded with modified GC electrodes. Scans started at $0.0 \mathrm{~V} . \omega=1600 \mathrm{rpm}, \nu: 5 \mathrm{mV} \cdot \mathrm{s}^{-1}$. Current densities shown by electrode geometric area. Plane impedance plots for (E) modified GC and (F) GR electrodes. Potential perturbation: $10 \mathrm{mV}$ (rms). Frequency range: $100 \mathrm{kHz}-10 \mathrm{mHz}$. Constant potential for EIS acquisition: $-50 \mathrm{mV}$ vs RHE. Inset in (E): plane impedance plots extended to $50 \mathrm{k} \Omega$. Inset in $(\mathrm{F})$ : plane impedance plots contracted to $15 \Omega$. HLSs (corrected for ohmicdrop resistance) for GC electrode modified with the $\beta-\mathrm{Ni}_{2} \mathrm{P}_{2} \mathrm{O}_{7} / \mathrm{Pt}$ electrocatalyst before and after $(\mathrm{G})$ the stability test $(10000$ cycles between 0.0 and $-0.1 \mathrm{~V}$ at $50 \mathrm{mV} \cdot \mathrm{s}^{-1}$ ) and $(\mathrm{H})$ chronoamperometric experiment (potential jumped from 0 to $-0.1 \mathrm{~V}$ vs RHE and kept at $-0.1 \mathrm{~V}$ vs RHE for 12 days, Figure S12). $\omega=1600 \mathrm{rpm}$; scan rate: $5 \mathrm{mV} \cdot \mathrm{s}^{-1}$. Scans started at $0.00 \mathrm{~V}$. Current densities shown by electrode geometric area. The results were obtained in $\mathrm{H}_{2}$-saturated $0.5 \mathrm{M} \mathrm{H}_{2} \mathrm{SO}_{4}$ solution with exception to inset of Figure $7 \mathrm{~A}$ that was obtained in $\mathrm{N}_{2}$-saturated $0.5 \mathrm{M} \mathrm{H}_{2} \mathrm{SO}_{4}$ solution.

and mass percentages (Table S5) were obtained from the XPS spectrum in Figure S6.

The $\beta-\mathrm{Ni}_{2} \mathrm{P}_{2} \mathrm{O}_{7}$ surface analysis from the XPS measurement (Figure S6) shows mass percentages of $\mathrm{Ni}(54 \%)$ and $\mathrm{P}(46 \%)$ (Table S5). However, to $\beta-\mathrm{Ni}_{2} \mathrm{P}_{2} \mathrm{O}_{7} / \mathrm{Pt}$, the surface analysis from the XPS measurement (Figure S6) shows mass percentages of $\mathrm{Ni}(72.7 \%), \mathrm{P}(20 \%)$, and $\mathrm{Pt}$ (7.3\%) (Table S5). The carbon and oxygen were not quantified because their contributions are totally from the graphite (GR) support surface to carbon and mixed contribution of support and the $\beta$ $\mathrm{Ni}_{2} \mathrm{P}_{2} \mathrm{O}_{7} / \mathrm{Pt}$ and $\beta-\mathrm{Ni}_{2} \mathrm{P}_{2} \mathrm{O}_{7} / \mathrm{Pt}$ surfaces to oxygen. The films of $\beta-\mathrm{Ni}_{2} \mathrm{P}_{2} \mathrm{O}_{7}$ and $\beta-\mathrm{Ni}_{2} \mathrm{P}_{2} \mathrm{O}_{7}$ on the GR surface did not have enough thickness to avoid the support surface contribution to XPS responses. However, even considering relative percentages (not including carbon and oxygen), Ni mass percentage is high than $\mathrm{P}$ as expected to $\beta-\mathrm{Ni}_{2} \mathrm{P}_{2} \mathrm{O}_{7}$ mass percentage composition as well as $\mathrm{Pt}$ mass percentage is lower than the $\mathrm{Ni}$ mass percentage and close to that determined by ICP-OES to $\beta$ $\mathrm{Ni}_{2} \mathrm{P}_{2} \mathrm{O}_{7} / \mathrm{Pt}$ mass percentage composition (see below).

The deconvoluted high-resolution $\mathrm{Ni} 2 \mathrm{p}$ XPS spectrum (Figure 6A) contains two peaks at 857.3 and $875.2 \mathrm{eV}$ with their respective satellites shakeup at 862.5 and $880.9 \mathrm{eV}$ corresponding to the $2 \mathrm{p}_{3 / 2}$ and $2 \mathrm{p}_{1 / 2}$ levels, respectively, in a 2:1 ratio (Table S6). A spin-orbital splitting of $18 \mathrm{eV}$ between the peaks and the presence of satellites peaks indicates that $\mathrm{Ni}^{2+}$ species ${ }^{32,52-55}$ are present at the $\beta-\mathrm{Ni}_{2} \mathrm{P}_{2} \mathrm{O}_{7}$ surface. In addition, the $\beta-\mathrm{Ni}_{2} \mathrm{P}_{2} \mathrm{O}_{7} / \mathrm{Pt}$ surface revealed two shoulders at $854.4\left(\mathrm{Ni} 2 \mathrm{p}_{3 / 2} \delta+\right)$ and $872.2\left(\mathrm{Ni} 2 \mathrm{p}_{1 / 2} \delta+\right)$ with small \% content (Figure 6A and Table S6) characteristic of a small amount of $\mathrm{Pt}$ in direct "contact" to $\mathrm{Ni}^{2+}$ species. These HRXPS spectra are narrowly connected to the EELS spectra in Figure 5A.

The deconvoluted $\mathrm{O} 1 \mathrm{~s}$ HR-XPS spectrum (Figure $6 \mathrm{~B}$ ) to $\beta$ $\mathrm{Ni}_{2} \mathrm{P}_{2} \mathrm{O}_{7}$ (there is a small peak in addition to a broad peak without deconvolution) assigned to $\mathrm{Ni}-\mathrm{O}(526.9 \mathrm{eV}), \mathrm{P}-\mathrm{O}-$ $\mathrm{P}(530.6 \mathrm{eV}),{ }^{53,54} \mathrm{C}-\mathrm{O}(532.0 \mathrm{eV})$, and $\mathrm{C}=\mathrm{O}(533.5 \mathrm{eV})$ groups, with large \% content of the last two groups (Table S6) because of the large contribution of the GR surface. To the $\beta$ $\mathrm{Ni}_{2} \mathrm{P}_{2} \mathrm{O}_{7} / \mathrm{Pt}$ surface (very broad two peaks without deconvolution are visible), in addition, there is clearly a new peak assigned to $\mathrm{Pt}-\mathrm{OH}(530.0 \mathrm{eV})$ group (Figure $6 \mathrm{~B}$ ) with small $\%$ content (Table S6), as expected due to the small amount of 
Pt present at $\beta-\mathrm{Ni}_{2} \mathrm{P}_{2} \mathrm{O}_{7} / \mathrm{Pt}$ (see ICP-OES result below). These HR-XPS spectra maintain close relationship to the EELS spectra in Figure 5B.

The deconvoluted P 2p HR-XPS spectrum (Figure 6C) to $\beta-\mathrm{Ni}_{2} \mathrm{P}_{2} \mathrm{O}_{7}$ (there is a broad peak without deconvolution) has been correlated to $\mathrm{P} 2 \mathrm{p}_{3 / 2}(134.0 \mathrm{eV})$ and $\mathrm{P} 2 \mathrm{p}_{1 / 2}(134.5 \mathrm{eV})$ peaks with $2 / 1$ ratio of $\%$ content for the first in relation to the second (Table S6), indicating a +5 state for $\mathrm{P}$ atoms ${ }^{52-55}$ in $\beta$ $\mathrm{Ni}_{2} \mathrm{P}_{2} \mathrm{O}_{7}$. To the $\beta-\mathrm{Ni}_{2} \mathrm{P}_{2} \mathrm{O}_{7} / \mathrm{Pt}$ surface (there are a broad peak followed by a shoulder without deconvolution), the peaks have been correlated to $\mathrm{P} 2 \mathrm{p}_{3 / 2}(134.4 \mathrm{eV})$ and $\mathrm{P} 2 \mathrm{p}_{1 / 2}(137.5 \mathrm{eV})$ also with $2 / 1$ ratio of $\%$ content for the first in relation to the second (Table S6), indicating also +5 state for $\mathrm{P}$ atoms ${ }^{52-55}$ in $\beta-\mathrm{Ni}_{2} \mathrm{P}_{2} \mathrm{O}_{7} / \mathrm{Pt}$. However, the displacement of $\mathrm{P} 2 \mathrm{p}_{1 / 2}$ peak from 134.5 to $137.5 \mathrm{eV}$ is an evidence of $\mathrm{Pt}$ in direct "contact" to $\mathrm{P}^{5+}$ species. These HR-XPS spectra maintain close relationship to the EELS spectra in Figure 5C.

Finally, the deconvoluted Pt 4f HR-XPS spectrum (Figure 6D) to $\beta-\mathrm{Ni}_{2} \mathrm{P}_{2} \mathrm{O}_{7} / \mathrm{Pt}$ revealed two peaks attributed to $\mathrm{Ni} 3 \mathrm{p}_{3 / 2}$ $(67.5 \mathrm{eV})$ and $\mathrm{Ni} 3 \mathrm{p}_{1 / 2}(69.4 \mathrm{eV})$, in addition to three couples (two spin-orbit split $(7 / 2,5 / 2)$ Pt $4 f$ peaks) of spin-orbit components (Pt $4 \mathrm{f}_{7 / 2}$ and $\mathrm{Pt} 4 \mathrm{f}_{5 / 2}$ ) with fixed separation (3.3 $\mathrm{eV})$ and a relative content ratio of $1.33 .^{46}$ The main $\mathrm{Pt} 4 \mathrm{f}_{7 / 2}$ component is located at $71.5 \mathrm{eV}$ and matches to metallic $\mathrm{Pt}^{46}$ with $\%$ content of $32 \%$ considering the two spin-orbit split. ${ }^{46}$ The another two components were attributed to $\mathrm{PtO}$ (72.8 $\mathrm{eV})$ and $\mathrm{PtO}_{2}(73.8 \mathrm{eV})^{46}$ (Table S6). The relatively high amount of $\mathrm{Pt}^{2+}$ and $\mathrm{Pt}^{4+}$ can originate from synthesis of the electrocatalyst in the presence of oxygen and further contact with oxygen during washing and storage. ${ }^{46}$ Definitely, we have metallic Pt NPs in direct "contact" with $\mathrm{Ni}^{2+}$ species in the $\beta$ $\mathrm{Ni}_{2} \mathrm{P}_{2} \mathrm{O}_{7} / \mathrm{Pt}$ structure positioned inside the "cages" of $\beta$ $\mathrm{Ni}_{2} \mathrm{P}_{2} \mathrm{O}_{7}$ (Scheme S1) and in direct "contact" with $\mathrm{Ni}^{2+}$ and $\mathrm{P}^{5+}$ species present in the $\beta-\mathrm{Ni}_{2} \mathrm{P}_{2} \mathrm{O}_{7}$ structure.

ICP-OES Analysis. To definitively confirm the Pt amount present in the $\beta-\mathrm{Ni}_{2} \mathrm{P}_{2} \mathrm{O}_{7} / \mathrm{Pt}$ sample, ICP-OES investigation was carried out. The Pt content (\% mass/mass) was examined by ICP-OES with obtainable value of $2.98 \pm 0.04$.

Electrochemical Profile. Figure 7A and Figures S7A,B and $\mathrm{S} 8 \mathrm{~A}-\mathrm{C}$ show the cyclic voltammetric profiles of bare $\mathrm{GC}$, bare $\mathrm{Pt}, \mathrm{Ni}_{3}\left(\mathrm{PO}_{4}\right)_{2}, \beta-\mathrm{Ni}_{2} \mathrm{P}_{2} \mathrm{O}_{7}, \mathrm{Ni}_{3}\left(\mathrm{PO}_{4}\right)_{2}{ }^{\prime}, \mathrm{Ni}_{3}\left(\mathrm{PO}_{4}\right)_{2} / \mathrm{Pt}, \beta$ $\mathrm{Ni}_{2} \mathrm{P}_{2} \mathrm{O}_{7} / \mathrm{Pt}, \mathrm{Ni}_{3}\left(\mathrm{PO}_{4}\right)_{2}^{\prime} / \mathrm{Pt}$, and 20 wt \% loading $\mathrm{Pt} /$ Vulcan supported on the GC surface $\left(\mathrm{Ni}_{3}\left(\mathrm{PO}_{4}\right)_{2} / \mathrm{GC}, \beta-\mathrm{Ni}_{2} \mathrm{P}_{2} \mathrm{O}_{7} / \mathrm{GC}\right.$, $\mathrm{Ni}_{3}\left(\mathrm{PO}_{4}\right)_{2}{ }^{\prime} / \mathrm{GC}, \mathrm{Ni}_{3}\left(\mathrm{PO}_{4}\right)_{2} / \mathrm{Pt} / \mathrm{GC}, \quad \beta-\mathrm{Ni}_{2} \mathrm{P}_{2} \mathrm{O}_{7} / \mathrm{Pt} / \mathrm{GC}$, $\mathrm{Ni}_{3}\left(\mathrm{PO}_{4}\right)_{2}^{\prime} / \mathrm{Pt} / \mathrm{GC}$, and Vulcan/Pt/GC-modified electrodes).

The bare GC, $\mathrm{Ni}_{3}\left(\mathrm{PO}_{4}\right)_{2} / \mathrm{GC}, \beta-\mathrm{Ni}_{2} \mathrm{P}_{2} \mathrm{O}_{7} / \mathrm{GC}$, and $\mathrm{Ni}_{3}\left(\mathrm{PO}_{4}\right)_{2}{ }^{\prime} / \mathrm{GC}$-modified electrodes show only capacitive current behavior in the entire potential window (Figure $7 \mathrm{~A}$ and Figure S8A). However, for $\beta-\mathrm{Ni}_{2} \mathrm{P}_{2} \mathrm{O}_{7} / \mathrm{Pt} / \mathrm{GC}$, it is more evident the region of adsorption/desorption of hydrogen in the potential window of 0.05 to $0.4 \mathrm{~V}$ (Figure 7A, Figures S7A and $\mathrm{S} 8 \mathrm{~A}, \mathrm{~B}$ ) (peak couples totally evidenced in the bare polycrystalline $\mathrm{Pt}$ (Figures S7A and S8B) at 0.12 and $0.26 \mathrm{~V}$ ) on the $\mathrm{Pt}$ surface, the region of double layer (capacitive currents, 0.4 to 0.75 V, Figure 7A, Figures S7A and S8A,B), and the region of Pt oxide formation (and reduction) from 0.74 to $1.2 \mathrm{~V}$ (a small Pt oxide reduction peak at $0.76 \mathrm{~V}$, Figure $7 \mathrm{~A}$, Figures S7A and S8A,B). For bare polycrystalline Pt (Figures S7A and S8B), the $\mathrm{Pt}$ oxide formation is totally visible by the currents from 0.80 to $1.2 \mathrm{~V}$, and the $\mathrm{Pt}$ oxide reduction characterized by a pronounced reduction peak at $0.82 \mathrm{~V}$. The amplified currents to the Vulcan/Pt/GC-modified electrode (Figures S7B and $\mathrm{S} 8 \mathrm{C}$ ) are due to the large capacitive currents from the Vulcan
XC72 carbon present at the 20 wt \% loading Pt/Vulcan electrocatalyst. The not well defined peak couples at the region of adsorption/desorption of hydrogen to the Vulcan/Pt/GCmodified electrode (Figures S7B and S8C) is related with the dispersion of $\mathrm{Pt}$ at Vulcan XC72 carbon. The $\mathrm{Pt}$ oxide formation to the Vulcan/Pt/GC-modified electrode (Figures S7B and S8C) is well visible by the large currents from 0.80 to $1.2 \mathrm{~V}$ and the $\mathrm{Pt}$ oxide reduction characterized by a pronounced reduction peak at $0.76 \mathrm{~V}$. The behavior of $\mathrm{Ni}_{3}\left(\mathrm{PO}_{4}\right)_{2} / \mathrm{Pt} / \mathrm{GC}$ and $\mathrm{Ni}_{3}\left(\mathrm{PO}_{4}\right)_{2}{ }^{\prime} / \mathrm{Pt} / \mathrm{GC}$-modified electrodes (Figure 7A and Figure S8A) is similar when compared with the $\mathrm{Pt}$ behavior observed at the $\beta-\mathrm{Ni}_{2} \mathrm{P}_{2} \mathrm{O}_{7} / \mathrm{Pt} / \mathrm{GC}$-modified electrode, exception to the high currents to the $\beta-\mathrm{Ni}_{2} \mathrm{P}_{2} \mathrm{O}_{7} / \mathrm{Pt} /$ GC-modified electrode in relation to the other two. The cyclic voltammetric profiles are very similar in $\mathrm{N}_{2}$-saturated $0.5 \mathrm{M}$ $\mathrm{H}_{2} \mathrm{SO}_{4}$ for all these electrodes (Figure S8A-C). Zheng et al. ${ }^{56}$ suggested that steady $\mathrm{H}_{2}$ pressure be preserved during the investigation to attain perfect $\mathrm{HER}$ polarization curves although $\mathrm{H}_{2}$ not being a reactant for HER. This is the justification for our electrochemical experiments to be mainly discussed at $\mathrm{H}_{2}$-saturated $0.5 \mathrm{M} \mathrm{H}_{2} \mathrm{SO}_{4}$ solution.

On the basis of responses in Figure 7A and Figures S7A,B, and $\mathrm{S} 8 \mathrm{~A}-\mathrm{C}$, it is possible to say that bare $\mathrm{Pt}$ and Vulcan/Pt/ GC-modified electrode present more $\mathrm{Pt}$ active sites than the $\beta$ $\mathrm{Ni}_{2} \mathrm{P}_{2} \mathrm{O}_{7} / \mathrm{Pt} / \mathrm{GC}$-modified electrode. To confirm this observation the ECSA values utilized to get current densities were examined from $\mathrm{H}_{\text {upd }}$-stripping to bare $\mathrm{Pt}$ and Vulcan/Pt/GCmodified electrode $\left(0.28\right.$ and $1.48 \mathrm{~cm}^{2}$, respectively, based on bare $\mathrm{Pt}$ and Vulcan/Pt/GC-modified electrode $\mathrm{CV}$ responses in Figures $\mathrm{S} 7 \mathrm{~A}, \mathrm{~B}$ and $\mathrm{S} 8 \mathrm{~B}, \mathrm{C})$ and $\mathrm{Cu}_{\mathrm{upd}}$-stripping to $\beta$ $\mathrm{Ni}_{2} \mathrm{P}_{2} \mathrm{O}_{7} / \mathrm{Pt} / \mathrm{GC}$-modified electrode measurements $\left(0.12 \mathrm{~cm}^{2}\right.$, Figure S9). The magenta curve in Figure S9 behaves likewise to those illustrated in Figure 7A, although the dashed black curve in Figure S9 shows an amplified current in comparison with magenta curve in all potential region that can be related to the exclusion of deposited $\mathrm{Cu}$ at $\mathrm{Pt}$ sites on the $\beta-\mathrm{Ni}_{2} \mathrm{P}_{2} \mathrm{O}_{7} / \mathrm{Pt}$ surface. $^{35}$

In addition, ECSA values estimated from $C_{\mathrm{dl}}$ (using eqs 1 and 2, CVs from Figure S10, and inclination values from inset in Figure $7 \mathrm{~A}$ ) to $\beta-\mathrm{Ni}_{2} \mathrm{P}_{2} \mathrm{O}_{7} / \mathrm{GC}$ and $\beta-\mathrm{Ni}_{2} \mathrm{P}_{2} \mathrm{O}_{7} / \mathrm{Pt} / \mathrm{GC}$ modified electrodes were 0.57 and $0.36 \mathrm{~cm}^{2}$, respectively. The presence of $\mathrm{Pt}$ at the $\beta-\mathrm{Ni}_{2} \mathrm{P}_{2} \mathrm{O}_{7} / \mathrm{Pt} / \mathrm{GC}$-modified electrode decreased the ECSA values estimated from $C_{\mathrm{dl}}$ in comparison with the $\beta-\mathrm{Ni}_{2} \mathrm{P}_{2} \mathrm{O}_{7} / \mathrm{GC}$-modified electrode. The Pt NPs inside the "cages" of $\beta-\mathrm{Ni}_{2} \mathrm{P}_{2} \mathrm{O}_{7}$ (Scheme $\mathrm{S} 1$ ) decreased the $\beta$ $\mathrm{Ni}_{2} \mathrm{P}_{2} \mathrm{O}_{7} /$ Pt ECSA.

Evaluation of the Electrocatalytic Activity of Modified $\mathrm{Ni}_{3}\left(\mathrm{PO}_{4}\right)_{2} / \mathrm{GC}, \beta-\mathrm{Ni}_{2} \mathrm{P}_{2} \mathrm{O}_{7} / \mathrm{GC}, \mathrm{Ni}_{3}\left(\mathrm{PO}_{4}\right)_{2}{ }^{\prime} / \mathrm{GC}$, $\mathrm{Ni}_{3}\left(\mathrm{PO}_{4}\right)_{2} / \mathrm{Pt} / \mathrm{GC}, \beta-\mathrm{Ni}_{2} \mathrm{P}_{2} \mathrm{O}_{7} / \mathrm{Pt} / \mathrm{GC}, \mathrm{Ni}_{3}\left(\mathrm{PO}_{4}\right)_{2}{ }^{\prime} / \mathrm{Pt} / \mathrm{GC}$, and Vulcan/Pt/GC Electrodes, and Bare $\mathrm{Pt}$ Electrode toward the HER. The HLS responses to bare Pt and GC electrodes and $\mathrm{Ni}_{3}\left(\mathrm{PO}_{4}\right)_{2} / \mathrm{GC}, \beta-\mathrm{Ni}_{2} \mathrm{P}_{2} \mathrm{O}_{7} / \mathrm{GC}, \mathrm{Ni}_{3}\left(\mathrm{PO}_{4}\right)_{2}^{\prime} /$ GC, $\mathrm{Ni}_{3}\left(\mathrm{PO}_{4}\right)_{2} / \mathrm{Pt} / \mathrm{GC}, \beta-\mathrm{Ni}_{2} \mathrm{P}_{2} \mathrm{O}_{7} / \mathrm{Pt} / \mathrm{GC}, \mathrm{Ni}_{3}\left(\mathrm{PO}_{4}\right)_{2}^{\prime} / \mathrm{Pt} /$ $\mathrm{GC}$, and Vulcan/Pt/GC-modified electrodes are shown in Figure 7B and Figures S7C and S8D.

It is worth noting that all electrochemical analyses were carried out by using a carbon paper HCP030N counter electrode instead of $\mathrm{Pt}$ counter electrode in line with the finest practices in pursuit of topic in heterogeneous electrocatalysis, ${ }^{57}$ because the $\mathrm{Pt}$ redeposition onto the working electrode from the $\mathrm{Pt}$ counter electrode (dissolution) should be avoided for HER catalysis studies. ${ }^{57-59}$ This care was not taken in several papers cited in Table S1. Also, for comparison, the 
commercially available 20 wt \% Pt/C (Vulcan/Pt) was used as a benchmarking catalyst, which is considered as a standard. ${ }^{57}$

For bare GC and GC electrodes modified with $\mathrm{Ni}_{3}\left(\mathrm{PO}_{4}\right)_{2}$, $\beta$ - $\mathrm{Ni}_{2} \mathrm{P}_{2} \mathrm{O}_{7}$, and $\mathrm{Ni}_{3}\left(\mathrm{PO}_{4}\right)_{2}{ }^{\prime}$ is not possible to see any catalytic effect for HER in the potential window shown in Figure $7 \mathrm{~B}$ and Figures S7C and S8D. However, to GC electrodes modified with $\mathrm{Ni}_{3}\left(\mathrm{PO}_{4}\right)_{2} / \mathrm{Pt}, \beta-\mathrm{Ni}_{2} \mathrm{P}_{2} \mathrm{O}_{7} / \mathrm{Pt}, \mathrm{Ni}_{3}\left(\mathrm{PO}_{4}\right)_{2}^{\prime} / \mathrm{Pt}$, and Vulcan/Pt and to bare $\mathrm{Pt}$, the high catalytic effect toward HER is clearly evident, mainly to bare $\mathrm{Pt}$, as expected, and also to Vulcan/Pt. The HLS response to the $\beta-\mathrm{Ni}_{2} \mathrm{P}_{2} \mathrm{O}_{7} / \mathrm{Pt} / \mathrm{GC}$ modified electrode appears at more positive potentials than to GC electrodes modified with $\mathrm{Ni}_{3}\left(\mathrm{PO}_{4}\right)_{2} / \mathrm{Pt}$ and $\mathrm{Ni}_{3}\left(\mathrm{PO}_{4}\right)_{2}{ }^{\prime} /$ $\mathrm{Pt}$ (see in Figures S7C and S8D the responses shown only in currents). At $-10 \mathrm{~mA} \cdot \mathrm{cm}^{-2}$, the overpotential to bare Pt was $10 \mathrm{mV}$, GC electrode modified with Vulcan/Pt was $16 \mathrm{mV}, \beta$ $\mathrm{Ni}_{2} \mathrm{P}_{2} \mathrm{O}_{7} / \mathrm{Pt}$ was $28 \mathrm{mV}, \mathrm{Ni}_{3}\left(\mathrm{PO}_{4}\right)_{2} / \mathrm{Pt}$ was $33 \mathrm{mV}$, and $\mathrm{Ni}_{3}\left(\mathrm{PO}_{4}\right)_{2}^{\prime} / \mathrm{Pt}$ was $58 \mathrm{mV}$, and at $-20 \mathrm{~mA} \cdot \mathrm{cm}^{-2}$, they were 19 , $30,41,53$, and $85 \mathrm{mV}$, respectively (Figure $7 \mathrm{~B}$ ), considering only the electrode geometric area. However, considering the ECSA based in upd-stripping (Figure S7D), the bare Pt and GC modified with $\beta-\mathrm{Ni}_{2} \mathrm{P}_{2} \mathrm{O}_{7} / \mathrm{Pt}$ and Vulcan/Pt had overpotential at $-10 \mathrm{~mA} \cdot \mathrm{cm}^{-2}$ of 16,20 , and $98 \mathrm{mV}$, respectively, and at $-20 \mathrm{~mA} \cdot \mathrm{cm}^{-2}$ of 30,32 , and $176 \mathrm{mV}$. The overpotential values to the $\beta-\mathrm{Ni}_{2} \mathrm{P}_{2} \mathrm{O}_{7} / \mathrm{Pt} / \mathrm{GC}$-modified electrode were lower than the value to the Vulcan/Pt/GC-modified electrode and very close to bare $\mathrm{Pt}$, considering the ECSA. In general, the overpotential values considering geometric area and ECSA are lower than the values summarized in Table S1. These results are in agreement with the idea that smaller crystalline sizes $(\beta$ $\mathrm{Ni}_{2} \mathrm{P}_{2} \mathrm{O}_{7}$ and $\left.\mathrm{Ni}_{3}\left(\mathrm{PO}_{4}\right)_{2}\right)$ result in higher electrocatalytic active surface, which in turn improves the HER electrocatalytic responses, in addition to the decreased distance of fringes from $\beta$ - $\mathrm{Ni}_{2} \mathrm{P}_{2} \mathrm{O}_{7}$ to $\beta$ - $\mathrm{Ni}_{2} \mathrm{P}_{2} \mathrm{O}_{7} / \mathrm{Pt}$ (TEM images in Figure 3 ), the detection of $\mathrm{Pt}$ very well distributed to $\beta-\mathrm{Ni}_{2} \mathrm{P}_{2} \mathrm{O}_{7}$ and closer to the $\mathrm{P}$ atoms, which reinforces the occurrence of small Pt NPs imbibed into the $\beta-\mathrm{Ni}_{2} \mathrm{P}_{2} \mathrm{O}_{7}$ structure (Figure 4), the presence of $\mathrm{Pt}$ at $\beta-\mathrm{Ni}_{2} \mathrm{P}_{2} \mathrm{O}_{7} / \mathrm{Pt}$ displacing the peaks in ELNES spectrum to high energy in comparison with the ELNES of $\beta-\mathrm{Ni}_{2} \mathrm{P}_{2} \mathrm{O}_{7}$, with not identifiable $\mathrm{P} \mathrm{L}_{1}$ peak to $\beta-\mathrm{Ni}_{2} \mathrm{P}_{2} \mathrm{O}_{7} / \mathrm{Pt}$ (Figure $5 \mathrm{C}$ ), and the presence of metallic Pt NPs in direct "contact" with $\mathrm{Ni}^{2+}$ species in the $\beta-\mathrm{Ni}_{2} \mathrm{P}_{2} \mathrm{O}_{7} / \mathrm{Pt}$ structure (Figure 6D) positioned inside the "cages" of $\beta-\mathrm{Ni}_{2} \mathrm{P}_{2} \mathrm{O}_{7}$ (Scheme S1) and in direct "contact" with $\mathrm{Ni}^{2+}$ and $\mathrm{P}^{5+}$ present in the $\beta-\mathrm{Ni}_{2} \mathrm{P}_{2} \mathrm{O}_{7}$ structure (Figure 6A,C). It is worth noting that the presence of $\mathrm{Pt}$ at the $\beta-\mathrm{Ni}_{2} \mathrm{P}_{2} \mathrm{O}_{7} / \mathrm{Pt} / \mathrm{GC}$-modified electrode decreased the ECSA values estimated from $C_{\mathrm{dl}}$ in comparison with the $\beta$ $\mathrm{Ni}_{2} \mathrm{P}_{2} \mathrm{O}_{7} / \mathrm{GC}$-modified electrode.

Using ECSA based on upd-stripping to compare the catalysts (bare $\mathrm{Pt}$ and GC-modified electrodes with $\beta$ $\mathrm{Ni}_{2} \mathrm{P}_{2} \mathrm{O}_{7} / \mathrm{Pt}$ and Vulcan/Pt) was possible to identify that GC electrode modified with $\beta-\mathrm{Ni}_{2} \mathrm{P}_{2} \mathrm{O}_{7} / \mathrm{Pt}$ is an excellent catalyst toward HER (better electrocatalytic behavior when compared with the Vulcan/Pt/GC-modified electrode and close to bare $\mathrm{Pt}$ electrode) because the amount of $\mathrm{Pt}$ available at GC electrode modified with $\beta-\mathrm{Ni}_{2} \mathrm{P}_{2} \mathrm{O}_{7} / \mathrm{Pt}$ is only close to $1.0 \mu \mathrm{g}$. $\mathrm{cm}^{-2}$, an almost negligible amount of $\mathrm{Pt}$ when compared with a bulk Pt electrode and eight times lower Pt amount (in mass) compared with Vulcan/Pt catalyst, which was used $8.0 \mu \mathrm{g} \cdot \mathrm{cm}^{-2}$ of Pt. The specific ECSA (see eq S1, Supporting Information) to the GC-modified electrode with $\beta-\mathrm{Ni}_{2} \mathrm{P}_{2} \mathrm{O}_{7} / \mathrm{Pt}$ was $61 \mathrm{~m}^{2}$. $\mathrm{g}_{\mathrm{Pt}}{ }^{-1}$, close to that reported by Neyerlin et al. ${ }^{60}$ using ultralow Pt-loaded electrodes $\left(3 \mu \mathrm{g} \cdot \mathrm{cm}^{-2}\right)$. In addition, the Pt and $\beta$ -
$\mathrm{Ni}_{2} \mathrm{P}_{2} \mathrm{O}_{7}$ loadings studied in the present work are lower than the loadings reported in Table S1.

By using ECSA estimated from $C_{\mathrm{dl}}$ and calculating the specific ECSA (eq S1) to the GC-modified electrode with $\beta$ $\mathrm{Ni}_{2} \mathrm{P}_{2} \mathrm{O}_{7}$ and $\beta-\mathrm{Ni}_{2} \mathrm{P}_{2} \mathrm{O}_{7} / \mathrm{Pt}$, we found 7.3 and $4.6 \mathrm{~m}^{2} \cdot \mathrm{g}_{\text {catalyst }}{ }^{-1}$. These values are coincident with the values of $6-7 \mathrm{~m}^{2} \cdot \mathrm{g}^{-1}$ determined by $\mathrm{BET}$ method to $\beta-\mathrm{Ni}_{2} \mathrm{P}_{2} \mathrm{O}_{7}, 32,61$ which Meguerdichian et al. ${ }^{61}$ concluded that $\beta-\mathrm{Ni}_{2} \mathrm{P}_{2} \mathrm{O}_{7}$ is nonporous. Our results of specific ECSA are totally coincident with the decreased distance of fringes detected to $\beta-\mathrm{Ni}_{2} \mathrm{P}_{2} \mathrm{O}_{7} / \mathrm{Pt}$ in relation to $\beta-\mathrm{Ni}_{2} \mathrm{P}_{2} \mathrm{O}_{7}$ catalyst (TEM image in Figure 3 ) as well as the occurrence of very well-distributed Pt NPs inside the "cages" of the $\beta-\mathrm{Ni}_{2} \mathrm{P}_{2} \mathrm{O}_{7}$ structure (Scheme $\mathrm{S} 1$ ).

The turnover frequency (TOF) (Figure S7E) was calculated using eqs $\mathrm{S} 2-\mathrm{S} 44^{62}$ and resulted at values of 154 and $51 \mathrm{~s}^{-1}$ based on ECSA obtained from $\mathrm{Cu}_{\mathrm{upd}}$ stripping and $C_{\mathrm{d} l}$, respectively, at an overpotential of $28 \mathrm{mV}\left(-10 \mathrm{~mA} \cdot \mathrm{cm}^{-2}\right.$ based on electrode geometric area, Figure 7B). These values are much higher than those reported by $\mathrm{Li}$ et al. ${ }^{62}$ even considering only our TOF values based on ECSA obtained from $C_{\mathrm{dl}}$. It is clear that some species are of constant TOF tendency at log scale at overpotentials higher than $100 \mathrm{mV}$ (Figure S7E). At $100 \mathrm{mV}$, the TOF values are 1461 and 500 $\mathrm{s}^{-1}$ based on ECSA obtained from $\mathrm{Cu}_{\mathrm{upd}}$ stripping and $C_{\mathrm{d},}$ respectively.

To understand better the electrocatalytic effect toward HER, the Tafel plots were produced (Figure $7 \mathrm{C}$ ) using data in Figure S7C.

It is clear that the linear behaviors to Tafel plots in the range of $\log |I|$ from -4 to -2 and from slope of these Tafel linear behaviors were calculated the " $\mathrm{mV} \cdot \mathrm{dec}^{-1}$ " (Table 1$)$. Also, for

Table 1. Tafel Slopes and Exchange Current Densities from HER for Modified GC Electrodes (Figure 7C)

\begin{tabular}{lccc}
$\begin{array}{c}\text { modified GC } \\
\text { electrode }\end{array}$ & $\begin{array}{c}\text { low } I \\
\left(\mathrm{mV} \cdot \mathrm{dec}^{-1}\right)\end{array}$ & $\begin{array}{c}j_{0}\left(\mathrm{~mA} \cdot \mathrm{cm}^{-2}\right) \\
\text { (by geometric } \\
\text { area) }\end{array}$ & $\begin{array}{c}j_{0}\left(\mathrm{~mA} \cdot \mathrm{cm}^{-2}\right)(\text { by } \\
\text { ECSA based on upd- } \\
\text { stripping })\end{array}$ \\
$\mathrm{Ni}_{3}\left(\mathrm{PO}_{4}\right)_{2} / \mathrm{Pt} / \mathrm{GC}$ & 37 & -1.13 & \\
$\beta-\mathrm{Ni}_{2} \mathrm{P}_{2} \mathrm{O}_{7} / \mathrm{Pt} / \mathrm{GC}$ & 32 & -1.31 & -2.14 \\
$\beta-\mathrm{Ni}_{2} \mathrm{P}_{2} \mathrm{O}_{7} / \mathrm{Pt} / \mathrm{GC}$ & 32 & -1.28 & -2.09 \\
after the 12 th day & & & \\
$\mathrm{Ni}_{3}\left(\mathrm{PO}_{4}\right)_{2}{ }^{\prime} / \mathrm{Pt} / \mathrm{GC}$ & 39 & -0.72 & \\
bare $\mathrm{Pt}$ & 29 & -4.22 & -2.47 \\
vulcan/Pt/GC & 30 & -2.73 & -0.36 \\
\hline
\end{tabular}

$\eta=0$ from Tafel linear behavior, the exchange current densities $\left(j_{0}\right)$ were obtained (Table 1$)$. The investigation of Tafel slope is an important parameter to expose the principal steps concerned in the mechanism of $\mathrm{H}_{2}$ evolution on electrocatalysts. Generally, the possible three principal reaction steps are Volmer reaction (eq 3), Heyrovsky reaction (eq 4), and Tafel reaction (eq 5)., $2,63,64$

$$
\begin{aligned}
& \mathrm{H}_{3} \mathrm{O}^{+}+\mathrm{e}^{-} \rightarrow \mathrm{H}_{\mathrm{ads}}+\mathrm{H}_{2} \mathrm{O}(\mathrm{RDS}: 120 \mathrm{mV}) \\
& \mathrm{H}_{3} \mathrm{O}^{+}+\mathrm{H}_{\mathrm{ads}}+\mathrm{e}^{-} \rightarrow \mathrm{H}_{2}+\mathrm{H}_{2} \mathrm{O}(\mathrm{RDS}: 40 \mathrm{mV}) \\
& \mathrm{H}_{\mathrm{ads}}+\mathrm{H}_{\mathrm{ads}} \rightarrow \mathrm{H}_{2}(\mathrm{RDS}: 30 \mathrm{mV})
\end{aligned}
$$

In light of the over three principal reaction steps, two mechanisms, namely, Volmer-Heyrovsky and Volmer-Tafel are probable for HER. As per this point, the bare $\mathrm{Pt}$ and the GC-modified electrodes with $\beta-\mathrm{Ni}_{2} \mathrm{P}_{2} \mathrm{O}_{7} / \mathrm{Pt}$ and Vulcan/Pt electrocatalysts with lower Tafel slopes $(\sim 30 \mathrm{mV} / \mathrm{dec})$ match 
to the Volmer-Tafel mechanism with Tafel reaction as a major rate limiting step. The GC-modified electrodes with $\mathrm{Ni}_{3}\left(\mathrm{PO}_{4}\right)_{2} / \mathrm{Pt}$ and $\mathrm{Ni}_{3}\left(\mathrm{PO}_{4}\right)_{2}{ }^{\prime} / \mathrm{Pt}$ electrocatalysts showed Tafel slopes of $37-39 \mathrm{mV} \cdot \mathrm{dec}^{-1}$ (Table 1), which corresponds to the Volmer-Heyrovsky mechanism with the Heyrovsky reaction as a major rate limiting step. These Tafel slopes are in line or even lower than the values summarized in Table S1.

The value of Tafel slope of $29 \mathrm{mV} \cdot \mathrm{dec}^{-1}$ (Table 1) to bare $\mathrm{Pt}$ is equal to that one reported in the literature of $30 \mathrm{mV}$. $\operatorname{dec}^{-1},{ }^{65,66}$ in addition to $j_{0}\left(-4.22\right.$ and $-2.47 \mathrm{~mA} \cdot \mathrm{cm}^{-2}$ per electrode geometric area and ECSA based on upd-stripping, respectively), higher than the reported in literature $\sim-1.00$ $\mathrm{mA} \cdot \mathrm{cm}^{-2} \cdot{ }^{65,66}$ The GC-modified electrodes with $\mathrm{Ni}_{3}\left(\mathrm{PO}_{4}\right)_{2} /$ Pt, $\beta-\mathrm{Ni}_{2} \mathrm{P}_{2} \mathrm{O}_{7} / \mathrm{Pt}$, Vulcan/Pt, and $\mathrm{Ni}_{3}\left(\mathrm{PO}_{4}\right)_{2}{ }^{\prime} / \mathrm{Pt}$ electrocatalysts showed Tafel slopes in an average of 39 to $30 \mathrm{mV}$. $\mathrm{dec}^{-1}$, close to the bare $\mathrm{Pt}$, and to GC-modified electrodes with $\mathrm{Ni}_{3}\left(\mathrm{PO}_{4}\right)_{2} / \mathrm{Pt}, \beta-\mathrm{Ni}_{2} \mathrm{P}_{2} \mathrm{O}_{7} / \mathrm{Pt}$, Vulcan/Pt, and $\mathrm{Ni}_{3}\left(\mathrm{PO}_{4}\right)_{2}{ }^{\prime} / \mathrm{Pt}$ electrocatalysts, the $j_{0}\left(-1.61 \mathrm{~mA} \cdot \mathrm{cm}^{-2}\right.$ in average $)$ was lower than that to bare Pt. However, considering the ECSA based on upd-stripping, the $j_{0}$ to the GC-modified electrode with the $\beta$ $\mathrm{Ni}_{2} \mathrm{P}_{2} \mathrm{O}_{7} / \mathrm{Pt}$ electrocatalyst was very close to bare $\mathrm{Pt}$ and six times higher in comparison with the GC-modified electrode with the Vulcan/Pt electrocatalyst (Table 1).

The GC-modified electrode with the $\beta-\mathrm{Ni}_{2} \mathrm{P}_{2} \mathrm{O}_{7} / \mathrm{Pt}$ electrocatalyst presents better results toward HER than that reported by Devadas and Imae ${ }^{22}$ to Pt NPs immobilized on graphene oxides, carbon nanohorns, and carbon nanotubes through a dendrimer-mediated chemical reaction, using $\sim 1$ wt $\%$ of $\mathrm{Pt}$ NPs, and even lower than the values reported in Table S1.

The HER electrocatalytic activity comparisons were made by decreasing systematically the amount of Pt used during the synthesis of $\beta-\mathrm{Ni}_{2} \mathrm{P}_{2} \mathrm{O}_{7} / \mathrm{Pt}$ electrocatalysts as well as with $\mathrm{Pt}$ $\mathrm{NP}$ electrocatalysts in relation to the $\beta-\mathrm{Ni}_{2} \mathrm{P}_{2} \mathrm{O}_{7} / \mathrm{Pt}(\sim 1.0 \mu \mathrm{g}$. $\mathrm{cm}^{-2}$ ) electrocatalyst (Figure 7D), and the HER electrocatalysis became worse from the sequence of $\beta-\mathrm{Ni}_{2} \mathrm{P}_{2} \mathrm{O}_{7} / \mathrm{Pt}$ $\left(\sim 0.5 \mu \mathrm{g} \cdot \mathrm{cm}^{-2}, 1.5\right.$ wt \%), Pt NP $\left(1.2 \mu \mathrm{g} \cdot \mathrm{cm}^{-2}\right)$, and $\beta$ $\mathrm{Ni}_{2} \mathrm{P}_{2} \mathrm{O}_{7} / \mathrm{Pt}\left(\sim 0.25 \mu \mathrm{g} \cdot \mathrm{cm}^{-2}, 0.5\right.$ wt \%) electrocatalysts. At $-10 \mathrm{~mA} \cdot \mathrm{cm}^{-2}$, the overpotentials are $28,111,232$, and 460 $\mathrm{mV}$, respectively (Figure 7D), this considers only the electrode geometric area. Importantly, the Pt NP $\left(1.2 \mu \mathrm{g} \cdot \mathrm{cm}^{-2}\right)$ electrocatalyst, which had approximately the same amount of $\mathrm{Pt}$ as the $\beta-\mathrm{Ni}_{2} \mathrm{P}_{2} \mathrm{O}_{7} / \mathrm{Pt}\left(\sim 1.0 \mu \mathrm{g} \cdot \mathrm{cm}^{-2}\right)$ electrocatalyst, showed much worse electrocatalysis than $\beta-\mathrm{Ni}_{2} \mathrm{P}_{2} \mathrm{O}_{7} / \mathrm{Pt}$ $\left(\sim 1.0 \mu \mathrm{g} \cdot \mathrm{cm}^{-2}\right)$, reinforcing the need of very well-distributed Pt NPs inside the "cages" of the $\beta-\mathrm{Ni}_{2} \mathrm{P}_{2} \mathrm{O}_{7}$ structure (Scheme $\mathrm{S} 1)$, with the lower limit of $\mathrm{Pt}$ amount to the $\beta-\mathrm{Ni}_{2} \mathrm{P}_{2} \mathrm{O}_{7} / \mathrm{Pt}$ electrocatalyst to present higher HER activity being found as $\sim 1.0 \mu \mathrm{g} \cdot \mathrm{cm}^{-2}$.

EIS experiments in different overpotentials were conducted at GC- and GR-modified electrodes (Figure 7E,F and Figure S11). In an overpotential of $50 \mathrm{mV}$ and GC-modified electrodes (Figure $7 \mathrm{E}$ ), the resistance to charge transfer $\left(R_{\mathrm{ct}}\right)$ is enormous to the $\beta-\mathrm{Ni}_{2} \mathrm{P}_{2} \mathrm{O}_{7} / \mathrm{GC}$ electrode $(\sim 340 \mathrm{k} \Omega), \sim 50$ $\mathrm{k} \Omega$ to $\beta-\mathrm{Ni}_{2} \mathrm{P}_{2} \mathrm{O}_{7} / \mathrm{Pt}\left(\sim 0.25 \mu \mathrm{g} \cdot \mathrm{cm}^{-2}, 0.5\right.$ wt $\left.\%\right) / \mathrm{GC}$ electrode, and $\sim 8.4 \mathrm{k} \Omega$ to Pt NPs $\left(1.2 \mu \mathrm{g} \cdot \mathrm{cm}^{-2}\right) / \mathrm{GC}$ electrode, and improved enough to $\beta-\mathrm{Ni}_{2} \mathrm{P}_{2} \mathrm{O}_{7} / \mathrm{Pt}\left(\sim 0.5 \mu \mathrm{g} \cdot \mathrm{cm}^{-2}, 1.5 \mathrm{wt}\right.$ $\%) /$ GC electrode $(\sim 780 \Omega)$, and definitively improved to $\beta$ $\mathrm{Ni}_{2} \mathrm{P}_{2} \mathrm{O}_{7} / \mathrm{Pt}\left(\sim 1 \mu \mathrm{g} \cdot \mathrm{cm}^{-2}, 3.0\right.$ wt \%)/GC electrode $(\sim 500 \Omega)$. In GR-modified electrodes (Figure $7 \mathrm{~F}$ ), the $R_{\mathrm{ct}}$ is also high to $\beta$ - $\mathrm{Ni}_{2} \mathrm{P}_{2} \mathrm{O}_{7} / \mathrm{GR}$ electrode (higher than $2.7 \mathrm{k} \Omega$ ) and $\sim 374 \Omega$ to $\beta-\mathrm{Ni}_{2} \mathrm{P}_{2} \mathrm{O}_{7} / \mathrm{Pt}\left(\sim 1.0 \mu \mathrm{g} \cdot \mathrm{cm}^{-2}, 3.0\right.$ wt $\left.\%\right) /$ GR electrode. The $R_{\mathrm{ct}}$ is decreased, increasing the overpotential from 10 to $50 \mathrm{mV}$ as well as changing from $\mathrm{H}_{2}$ - to $\mathrm{N}_{2}$-saturated $0.5 \mathrm{M} \mathrm{H}_{2} \mathrm{SO}_{4}$ solution (Figure S11). The increased overpotential facilitates the charge transfer from the modified electrode to produce $\mathrm{H}_{2}$ as well as the $\mathrm{H}_{2}$-saturated $0.5 \mathrm{M} \mathrm{H}_{2} \mathrm{SO}_{4}$ solution slightly difficult the charge transfer from the modified electrode to produce $\mathrm{H}_{2}$.

The $\beta-\mathrm{Ni}_{2} \mathrm{P}_{2} \mathrm{O}_{7} / \mathrm{Pt}\left(\sim 1 \mu \mathrm{g} \cdot \mathrm{cm}^{-2}, 3.0\right.$ wt $\left.\%\right) / \mathrm{GC}($ or GR) electrode presents the most facilitated charge transfer to produce $\mathrm{H}_{2}$ (Figure 7E,F and Figure S11) because of the ideal synergistic effect between the amount of Pt NPs inside of the $\beta-\mathrm{Ni}_{2} \mathrm{P}_{2} \mathrm{O}_{7}$ structure and their distribution on the electrode surface.

Electrocatalytic Stability Tests. GC modified with the $\beta$ $\mathrm{Ni}_{2} \mathrm{P}_{2} \mathrm{O}_{7} / \mathrm{Pt}$ electrode was tested for stability in $\mathrm{H}_{2}$-saturated $0.5 \mathrm{M} \mathrm{H}_{2} \mathrm{SO}_{4}$ at a potential scan rate of $50 \mathrm{mV} \cdot \mathrm{s}^{-1}$ for 10,000 cycles between 0.0 and $-0.1 \mathrm{~V}$ or keeping constant the potential at $-0.1 \mathrm{~V}$ (skipping the potential from 0 to $-0.1 \mathrm{~V}$, chronoamperometric experiment) and following the current with time for 12 days (Figure S12). ${ }^{67}$ The GC electrode modified with $\beta-\mathrm{Ni}_{2} \mathrm{P}_{2} \mathrm{O}_{7} / \mathrm{Pt}$ was kept in stationary state, and it was not tilted in relation to the electrochemical cell. The chronoamperometric result is shown in Figure S12 in which the case is observed an increase in current densities after each initiated day of chronoamperometric experiment from in average -1.75 until $-0.50 \mathrm{~mA} \cdot \mathrm{cm}^{-2}$ (stable currents) after few hours. This increase in current densities as well as the overall low current densities can be attributed to the GC electrode modified with $\beta-\mathrm{Ni}_{2} \mathrm{P}_{2} \mathrm{O}_{7} / \mathrm{Pt}$ being kept in stationary state and not tilted in relation to the electrochemical cell, in addition to the constant production of $\mathrm{H}_{2}$ macro- (photo in Figure S12), micro-, and nanobubbles blocking the electrocatalytic $\mathrm{Pt}$ surface on the $\beta-\mathrm{Ni}_{2} \mathrm{P}_{2} \mathrm{O}_{7} / \mathrm{Pt}$ electrocatalyst.

The HLS readings obtained before and after testing are depicted in Figure 7G,H and Figure S11. To GC electrode modified with $\beta-\mathrm{Ni}_{2} \mathrm{P}_{2} \mathrm{O}_{7} / \mathrm{Pt}$, the overpotential decreased by $6 \%$ (after 5000 cycles) and remained the same (after 10000 cycles) at $-10 \mathrm{~mA} \cdot \mathrm{cm}^{-2}$ in relation to initial situation (before cycles) and decreased 15\% (after 5000 cycles) and 8\% (after 10000 cycles) at $-20 \mathrm{~mA} \cdot \mathrm{cm}^{-2}$ in relation to initial situation (Figure $7 \mathrm{G}$ ). The overpotential remained the same (after the 12th day) at $-10 \mathrm{~mA} \cdot \mathrm{cm}^{-2}$, and increased $10 \%$ (after the 12 th day) at $-20 \mathrm{~mA} \cdot \mathrm{cm}^{-2}$ in relation to initial situation (Figure $7 \mathrm{H})$. To GR electrode modified with the $\beta-\mathrm{Ni}_{2} \mathrm{P}_{2} \mathrm{O}_{7} / \mathrm{Pt}$ electrocatalyst, the overpotentials are improved after the 12th day to linear potential scan experiments conducted in the presence of $\mathrm{N}_{2}$ - and $\mathrm{H}_{2}$-saturated $0.5 \mathrm{M} \mathrm{H}_{2} \mathrm{SO}_{4}$ solution (Figure S11).

The stability of the $\beta-\mathrm{Ni}_{2} \mathrm{P}_{2} \mathrm{O}_{7} / \mathrm{Pt}$ electrocatalyst was maintained after 10,000 cycles and after 12 days of chronoamperometric measurements and importantly, at -0.1 $\mathrm{V}$, will present current densities higher than $-40 \mathrm{~mA} \cdot \mathrm{cm}^{-2}$. The Tafel (Figure 7C) slope to GC electrode modified with the $\beta-\mathrm{Ni}_{2} \mathrm{P}_{2} \mathrm{O}_{7} / \mathrm{Pt}$ electrocatalyst after stability test is equal (32 $\left.\mathrm{mV} \cdot \mathrm{dec}^{-1}\right)$ to $\mathrm{GC}$ electrode modified with the $\beta-\mathrm{Ni}_{2} \mathrm{P}_{2} \mathrm{O}_{7} / \mathrm{Pt}$ electrocatalyst before stability test and $j_{0}$ is also equal after the stability test (Table 1 ).

The $\beta-\mathrm{Ni}_{2} \mathrm{P}_{2} \mathrm{O}_{7} / \mathrm{Pt}$ electrocatalyst after 12 days of chronoamperometric measurements showed a visible distance of fringes of $0.19-0.22 \mathrm{~nm}$ (HR-TEM image A in Figure 3) similar to Pt NPs (HR-TEM image A in Figure S4), mean PSD of $13.7 \pm 3.9 \mathrm{~nm}$ (Figure S3), revealing some increase in $\mathrm{Pt}$ NPs size, EDX mapping with the decreased presence of $\mathrm{Ni}$ and $\mathrm{O}$, and the substantial presence of Pt circled by $\mathrm{P}$ (Figure 4), in addition to diffraction pattern consistent with the spots in 
distances corresponding to (111), (200), (220), and (311) planes typical of Pt materials with fcc crystalline patterns ${ }^{43-47}$ such as Pt NP sample (Figure S4B).

The $\beta-\mathrm{Ni}_{2} \mathrm{P}_{2} \mathrm{O}_{7} / \mathrm{Pt}$ electrocatalyst after 12 days of chronoamperometric measurements showed only distinguishable $\mathrm{O} 1 \mathrm{~s}$ and $\mathrm{C} 1 \mathrm{~s}$ peaks at the XPS spectrum (Figure S6), with total carbon contribution originated from the GR support surface and mixed contribution of support surface and the $\beta$ $\mathrm{Ni}_{2} \mathrm{P}_{2} \mathrm{O}_{7} / \mathrm{Pt}$ electrocatalyst surface after 12 days of chronoamperometric measurements to oxygen. The high-resolution $\mathrm{Ni} 2 \mathrm{p}$ XPS spectrum (Figure 6A) does not evidence the $\mathrm{Ni}$ presence on the $\beta-\mathrm{Ni}_{2} \mathrm{P}_{2} \mathrm{O}_{7} / \mathrm{Pt}$ electrocatalyst surface because of the accentuated $\mathrm{Ni}$ dissolution after 12 days of chronoamperometric measurements. The deconvoluted $\mathrm{O} 1 \mathrm{~s}$ HR-XPS spectrum (Figure $6 \mathrm{~B}$ ) to the $\beta-\mathrm{Ni}_{2} \mathrm{P}_{2} \mathrm{O}_{7} / \mathrm{Pt}$ electrocatalyst surface after 12 days of chronoamperometric measurements (it is visible a broad peak without deconvolution) presents a peak assigned to $\mathrm{Ni}-\mathrm{O}(528.7 \mathrm{eV})$ group with very small \% content (Table S6) and a peak assigned to $\mathrm{Pt}-\mathrm{OH}$ $(530.5 \mathrm{eV})$ group (Figure 6B) with high \% content (Table S6) in comparison with the $\beta-\mathrm{Ni}_{2} \mathrm{P}_{2} \mathrm{O}_{7} / \mathrm{Pt}$ surface (Table S6), revealing a decreased amount of $\mathrm{Ni}$ to the $\beta-\mathrm{Ni}_{2} \mathrm{P}_{2} \mathrm{O}_{7} / \mathrm{Pt}$ surface after 12 days of chronoamperometric measurements, in accordance with the EDX mapping response (Figure 4). The deconvoluted P 2p HR-XPS spectrum (Figure 6C) to the $\beta$ $\mathrm{Ni}_{2} \mathrm{P}_{2} \mathrm{O}_{7} / \mathrm{Pt}$ surface after 12 days of chronoamperometric measurements (there is a broad peak followed by a small shoulder without deconvolution) has been correlated to $\mathrm{P}$ $2 \mathrm{p}_{3 / 2}(134.3 \mathrm{eV})$ and $\mathrm{P} 2 \mathrm{p}_{1 / 2}(135.5 \mathrm{eV})$ peaks with $2 / 1$ ratio of $\%$ content for the first in relation to the second (Table S6), indicating also +5 state for $\mathrm{P}$ atoms. ${ }^{52-55}$ The displacement of P $2 \mathrm{p}_{1 / 2}$ peak from 137.5 to $135.5 \mathrm{eV}\left(\beta-\mathrm{Ni}_{2} \mathrm{P}_{2} \mathrm{O}_{7} / \mathrm{Pt}\right.$ surface in relation to $\beta-\mathrm{Ni}_{2} \mathrm{P}_{2} \mathrm{O}_{7} / \mathrm{Pt}$ surface after 12 days of chronoamperometric measurements) is an evidence of Pt being in direct "contact" to $\mathrm{P}^{5+}$ species with decreased "contact" with $\mathrm{Ni}$ (the amount of Ni was enough decreased) (see also EDX mapping, Figure 4). Finally, the deconvoluted $\mathrm{Pt} 4 \mathrm{f}$ HR-XPS spectrum (Figure 6D) to the $\beta-\mathrm{Ni}_{2} \mathrm{P}_{2} \mathrm{O}_{7} / \mathrm{Pt}$ surface after 12 days of chronoamperometric measurements revealed two peaks attributed to $\mathrm{Ni} 3 \mathrm{p}_{3 / 2}(66.9 \mathrm{eV})$ and $\mathrm{Ni} 3 \mathrm{p}_{1 / 2}(68.9 \mathrm{eV})$, in addition to three couples (two spin-orbit split $(7 / 2,5 / 2) \mathrm{Pt} 4 \mathrm{f}$ peaks) of spin-orbit components ( $\mathrm{Pt} 4 \mathrm{f}_{7 / 2}$ and $\mathrm{Pt} 4 \mathrm{f}_{5 / 2}$ ) with fixed separation $(2.9 \mathrm{eV})$ and a relative content ratio of 0.75 . The main $\mathrm{Pt} 4 \mathrm{f}_{7 / 2}$ component is located at $71.1 \mathrm{eV}$ and corresponds to metallic $\mathrm{Pt}^{46}$ with \% content of $29 \%$ considering the two spin-orbit split. ${ }^{46}$ The other two components were attributed to $\mathrm{PtO}(71.9 \mathrm{eV})$ and $\mathrm{PtO}_{2}$ $(73.2 \mathrm{eV})^{46}$ (Table S6). The relatively amount of $\mathrm{Pt}^{2+}$ and $\mathrm{Pt}^{4+}$ in relation to $\mathrm{Pt}^{0}$ is not different (comparing the $\beta$ $\mathrm{Ni}_{2} \mathrm{P}_{2} \mathrm{O}_{7} / \mathrm{Pt}$ surface after 12 days of chronoamperometric measurements with the $\beta-\mathrm{Ni}_{2} \mathrm{P}_{2} \mathrm{O}_{7} / \mathrm{Pt}$ surface) from the original amount of $\mathrm{Pt}^{2+}$ and $\mathrm{Pt}^{4+}$ attributed to be originate from synthesis of the electrocatalyst in the presence of oxygen and further contact with oxygen during washing and storage. ${ }^{46}$ Definitely, we have metallic Pt NPs in direct "contact" with $\mathrm{Ni}^{2+}$ and $\mathrm{P}^{5+}$ species present in the $\beta-\mathrm{Ni}_{2} \mathrm{P}_{2} \mathrm{O}_{7} / \mathrm{Pt}$ structure after 12 days of chronoamperometric measurements (see also EDX mapping, Figure 4).

Additionally, the GR-modified with the $\beta-\mathrm{Ni}_{2} \mathrm{P}_{2} \mathrm{O}_{7} / \mathrm{Pt}$ electrocatalyst after 12 days of chronoamperometric measurements showed decreased $R_{\mathrm{ct}}$ to produce $\mathrm{H}_{2}$ with the increased overpotential and in $\mathrm{H}_{2}$-saturated $0.5 \mathrm{M} \mathrm{H}_{2} \mathrm{SO}_{4}$ solution
(Figure $7 \mathrm{~F}$ and Figure S11), with the best result of $5 \Omega$ (very small $R_{\mathrm{ct}}$ value).

These combined information reflects-even occurring $\mathrm{Ni}$ dissolution and loss of oxygen atoms to $\beta-\mathrm{Ni}_{2} \mathrm{P}_{2} \mathrm{O}_{7} / \mathrm{Pt}$ structure-that Pt NPs surrounded (in "contact") by P (in addition to $\mathrm{Ni}$ with decreased amount in overall structure) atoms-this ideal combination-very well distributed on the electrode surface, keep high electrocatalytic activity toward HER, inclusive due to the tremendous facility of charge transfer of this combined system to produce $\mathrm{H}_{2}$.

The impressive HER electrocatalytic efficiency to the $\beta$ $\mathrm{Ni}_{2} \mathrm{P}_{2} \mathrm{O}_{7} / \mathrm{Pt}$ electrocatalyst can be attributed initially to the small crystalline size of $\beta-\mathrm{Ni}_{2} \mathrm{P}_{2} \mathrm{O}_{7}$ in comparison with $\mathrm{Ni}_{3}\left(\mathrm{PO}_{4}\right)_{2}$ and $\mathrm{Ni}_{3}\left(\mathrm{PO}_{4}\right)_{2}{ }^{\prime}$. Also, $\left(\mathrm{Ni}_{3}\left(\mathrm{PO}_{4}\right)_{2} / \mathrm{Pt}\right.$ is the best HER catalyst than $\mathrm{Ni}_{3}\left(\mathrm{PO}_{4}\right)_{2}{ }^{\prime} / \mathrm{Pt}, \mathrm{Ni}_{3}\left(\mathrm{PO}_{4}\right)_{2}$ has lower crystalline size than $\mathrm{Ni}_{3}\left(\mathrm{PO}_{4}\right)_{2}^{\prime}$, coupled with:

(1) very well-distributed Pt NPs inside of the "cages" on the $\beta-\mathrm{Ni}_{2} \mathrm{P}_{2} \mathrm{O}_{7}$ structure with a crystalline pattern of $0.67 \mathrm{~nm}$ in distance, helping the Volmer-Tafel mechanismTafel reaction as a major rate limiting step-to liberate very fast the $\mathrm{Pt}$ sites after HER. The GC-modified electrodes with $\mathrm{Ni}_{3}\left(\mathrm{PO}_{4}\right)_{2} / \mathrm{Pt}$ and $\mathrm{Ni}_{3}\left(\mathrm{PO}_{4}\right)_{2}{ }^{\prime} / \mathrm{Pt}$ electrocatalysts showed Tafel slopes corresponding to the Volmer-Heyrovsky mechanism with Heyrovsky reaction as a major rate limiting step, which appears to liberate more slowly the Pt sites after HER.

(2) the synergic effect between $\mathrm{Pt}$ and $\mathrm{Ni} / \mathrm{P}$ (the direct "contact" between metallic Pt NPs with $\mathrm{Ni}^{2+}$ and $\mathrm{P}^{5+}$ species present in the $\beta-\mathrm{Ni}_{2} \mathrm{P}_{2} \mathrm{O}_{7}$ structure, facilitating enormously the charge transfer to HER by strongly decreasing the $R_{\mathrm{ct}}$ from the $\beta-\mathrm{Ni}_{2} \mathrm{P}_{2} \mathrm{O}_{7}$ to $\beta-\mathrm{Ni}_{2} \mathrm{P}_{2} \mathrm{O}_{7} / \mathrm{Pt}$ catalyst) may decrease the hydrogen adsorption energy at the Pt NP surface, facilitating the liberation of Pt sites during HER, when compared with electrocatalysts involving only Pt (Pt NPs, bare Pt, and Vulcan/Pt).

(3) the structure of $\beta-\mathrm{Ni}_{2} \mathrm{P}_{2} \mathrm{O}_{7}$ containing very welldistributed Pt NPs inside their cages is sufficiently stable (strong "contact" between Pt NPs and P-in addition to $\mathrm{Ni}$ with decreased amount in overall structure after stability test-atoms) in such harsh acidic environment used in the present work because it was able to support stationary stability tests (not tilted GC modified with $\beta$ $\mathrm{Ni}_{2} \mathrm{P}_{2} \mathrm{O}_{7} / \mathrm{Pt}$ electrode in relation to the electrochemical cell) involving reasonable current densities. After stability tests the $\beta-\mathrm{Ni}_{2} \mathrm{P}_{2} \mathrm{O}_{7} / \mathrm{Pt}$ electrode presented the lower $R_{\mathrm{ct}}$ value, meaning very fast charge transfer from the modified electrode to $\mathrm{H}_{2}$ production.

\section{CONCLUSIONS}

In summary, hierarchically structured $\mathrm{Ni}_{3}\left(\mathrm{PO}_{4}\right)_{2}$ was synthesized by two different synthetic routes, namely, simple costeffective precipitation and solution combustion processes, and $\beta-\mathrm{Ni}_{2} \mathrm{P}_{2} \mathrm{O}_{7}$ by precipitation method. Using these as precursors, nickel pyrophosphate and nickel phosphate/Pt composites $\left(\mathrm{Ni}_{3}\left(\mathrm{PO}_{4}\right)_{2} / \mathrm{Pt}, \mathrm{Ni}_{3}\left(\mathrm{PO}_{4}\right)_{2}{ }^{\prime} / \mathrm{Pt}\right.$ and $\left.\beta-\mathrm{Ni}_{2} \mathrm{P}_{2} \mathrm{O}_{7} / \mathrm{Pt}\right)$ were prepared by using potassium hexachloroplatinate and ascorbic acid. The developed nickel pyrophosphate and nickel phosphate/Pt materials were employed as a low-cost advanced electrocatalysts for HER by water splitting. The structure purity and surface morphology of the samples were exposed by different analytical techniques such as XRD, FE-SEM, TEM, HR-TEM, electron diffraction pattern, HAADF-STEM, EDX 
mapping images, EELS, FT-IR, XPS, ICP-OES, and EIS analyses. The complete electrochemical studies exposed that the $\beta-\mathrm{Ni}_{2} \mathrm{P}_{2} \mathrm{O}_{7} / \mathrm{Pt}$ electrocatalyst exhibited an excellent electrocatalytic activity for HER in acidic solution than the other samples with an overpotential of $28 \mathrm{mV}$ at $-10 \mathrm{~mA}$. $\mathrm{cm}^{-2}$, a Tafel slope of $32 \mathrm{mV} \cdot \mathrm{dec}^{-1}$, an $j_{0}$ of $-1.31 \mathrm{~mA} \cdot \mathrm{cm}^{-2}$, and TOF values of 1461 and $500 \mathrm{~s}^{-1}$ based on ECSA obtained from $\mathrm{Cu}_{\text {upd }}$ stripping and $C_{\mathrm{d}}$, respectively, at an overpotential of $100 \mathrm{mV}$. Moreover, the $\beta-\mathrm{Ni}_{2} \mathrm{P}_{2} \mathrm{O}_{7} / \mathrm{Pt}$ electrocatalyst sustains a good stability for over 10,000 cycles or $-0.1 \mathrm{~V}$ versus RHE for 12 days. The present investigation demonstrates that the $\beta-\mathrm{Ni}_{2} \mathrm{P}_{2} \mathrm{O}_{7} / \mathrm{Pt}$ material could be a promising cost-effective electrocatalyst for $\mathrm{H}_{2}$ production.

\section{ASSOCIATED CONTENT}

\section{S Supporting Information}

The Supporting Information is available free of charge on the ACS Publications website at DOI: 10.1021/acsami.8b18153.

Experimental details, scheme, figures, equations, and tables concerning supplementary results and references (PDF)

\section{AUTHOR INFORMATION}

\section{Corresponding Author}

*E-mail: gilberto.maia@ufms.br. Tel.: +55 673345 3551. Fax: +556733453552.

\section{ORCID}

Jayaraman Theerthagiri: 0000-0002-5746-5541

Jagannathan Madhavan: 0000-0003-4005-4604

Gilberto Maia: 0000-0003-2449-0887

\section{Author Contributions}

${ }^{\dagger}$ These authors contributed equally to this work.

\section{Author Contributions}

The manuscript was written through contributions of all authors. All authors have given approval to the final version of the manuscript.

\section{Notes}

The authors declare no competing financial interest.

\section{ACKNOWLEDGMENTS}

G.M. wishes to thank the LME-IQSC-USP-São Carlos for the TEM facilities, the LABNANO/CBPF for technical support during electron microscopy EELS measurements, the LAMAS - Laboratório Multiusuário de Análise de Superficies from UFRGS for the XPS facilities, GFQM-IQ-UNESP for the XRD facilities, and CNPq (grants 301403/2011-2, 473991/2012-8, 405695/2013-6, 303759/2014-3, and 442268/2014-9) and Fundect-MS (grants 23/200.583/2012, 23/200.735/2012, 23/ 200.246/2014, and 59/300.184/2016) for their financial support. E.S.F.C. thanks Fundect-MS (grant 23/200.675/ 2014), and G.V.F. thanks CAPES for the fellowship. This study was financed in part by the Coordenação de Aperfeiçoamento de Pessoal de Nivel Superior - Brasil (CAPES) - Finance Code 001. In addition, B.S. gratefully acknowledges the DST (SERB), New Delhi, India for providing the fellowship (PDF/ 2015/000217).

\section{REFERENCES}

(1) Murthy, A. P.; Theerthagiri, J.; Madhavan, J.; Murugan, K. Highly Active $\mathrm{MoS}_{2} /$ Carbon Electrocatalysts for the Hydrogen Evolution Reaction - Insight into the Effect of the Internal Resistance and Roughness Factor on the Tafel Slope. Phys. Chem. Chem. Phys. 2017, 19, 1988-1998.

(2) Theerthagiri, J.; Sudha, R.; Premnath, K.; Arunachalam, P.; Madhavan, J.; Al-Mayouf, A. M. Growth of Iron Diselenide Nanorods on Graphene Oxide Nanosheets as Advanced Electrocatalyst for Hydrogen Evolution Reaction. Int. J. Hydrogen Energy 2017, 42, 13020-13030.

(3) Theerthagiri, J.; Senthil, R. A.; Senthilkumar, B.; Polu, A. R.; Madhavan, J.; Ashokkumar, M. Recent Advances in $\mathrm{MoS}_{2}$ Nanostructured Materials for Energy and Environmental Applications - A Review. J. Solid State Chem. 2017, 252, 43-71.

(4) Li, X.; Ci, S.; Jia, J.; Wen, Z. Graphene Loading Molybdenum Carbide/Oxide Hybrids as Advanced Electrocatalysts for Hydrogen Evolution Reaction. Int. J. Hydrogen Energy 2016, 41, 21246-21250.

(5) Guo, B.; Yu, K.; Li, H.; Song, H.; Zhang, Y.; Lei, X.; Fu, H.; Tan, Y.; Zhu, Z. Hollow Structured Micro/Nano $\mathrm{MoS}_{2}$ Spheres for Highly Electrocatalytic Activity Hydrogen Evolution Reaction. ACS Appl. Mater. Interfaces 2016, 8, 5517-5525.

(6) Hou, D.; Zhou, W.; Liu, X.; Zhou, K.; Xie, J.; Li, G.; Chen, S. Pt Nanoparticles/ $\mathrm{MoS}_{2}$ Nanosheets/Carbon Fibers as Efficient Catalyst for the Hydrogen Evolution Reaction. Electrochim. Acta 2015, 166, 26-31.

(7) Dai, X.; Li, Z.; Du, K.; Sun, H.; Yang, Y.; Zhang, X.; Ma, X.; Wang, J. Facile Synthesis of In-Situ Nitrogenated Graphene Decorated by Few-Layer $\mathrm{MoS}_{2}$ for Hydrogen Evolution Reaction. Electrochim. Acta 2015, 171, 72-80.

(8) Chen, Y-q.; Zhang, J-f.; Wan, L.; Hu, W.-b.; Liu, L.; Zhong, C.; Deng, Y.-d. Effect of Nickel Phosphide Nanoparticles Crystallization on Hydrogen Evolution Reaction Catalytic Performance. Trans. Nonferrous Met. Soc. China 2017, 27, 369-376.

(9) Fang, Z.; Wang, Y.; Zou, Y.; Hao, Z.; Dong, Q. One-Pot Synthesis of Nickel Sulfide with Sulfur Powder as Sulfur Source in Solution and Their Electrochemical Properties for Hydrogen Evolution Reaction. Inorg. Chem. Commun. 2017, 79, 1-4.

(10) Gao, Z.; Qi, J.; Chen, M.; Zhang, W.; Cao, R. An Electrodeposited NiSe for Electrocatalytic Hydrogen and Oxygen Evolution Reactions in Alkaline Solution. Electrochim. Acta 2017, 224, $412-418$.

(11) Zhang, Y.; Zang, J.; Jia, S.; Tian, P.; Han, C.; Wang, Y. Low Content of Pt Supported on $\mathrm{Ni}-\mathrm{MoC}_{x} /$ Carbon Black as a Highly Durable and Active Electrocatalyst for Methanol Oxidation, Oxygen Reduction and Hydrogen Evolution Reactions in Acidic Condition. Appl. Surf. Sci. 2017, 412, 327-334.

(12) Deng, Z.; Wang, J.; Nie, Y.; Wei, Z. Tuning the Interface of $\mathrm{Ni} @ \mathrm{Ni}(\mathrm{OH})_{2} / \mathrm{Pd} / \mathrm{rGO}$ Catalyst to Enhance Hydrogen Evolution Activity and Stability. J. Power Sources 2017, 352, 26-33.

(13) Ashassi-Sorkhabi, H.; Rezaei-Moghadam, B.; Asghari, E.; Bagheri, R.; Hosseinpour, Z. Fabrication of Bridge Like Pt@ MWCNTs/ $\mathrm{CoS}_{2}$ Electrocatalyst on Conductive Polymer Matrix for Electrochemical Hydrogen Evolution. Chem. Eng. J. 2017, 308, 275288.

(14) Anantharaj, S.; Karthik, P. E.; Subramanian, B.; Kundu, S. Pt Nanoparticles Anchored Molecular Self-assemblies of DNA: An Extremely Stable and Efficient HER Electrocatalyst with Ultralow Pt Content. ACS Catal. 2016, 6, 4660-4672.

(15) Wang, L.; Zhu, Y.; Zeng, Z.; Lin, C.; Giroux, M.; Jiang, L.; Han, Y.; Greeley, J.; Wang, C.; Jin, J. Platinum-Nickel Hydroxide Nanocomposites for Electrocatalytic Reduction of Water. Nano Energy 2017, 31, 456-461.

(16) Kemppainen, E.; Bodin, A.; Sebok, B.; Pedersen, T.; Seger, B.; Mei, B.; Bae, D; Vesborg, P. C. K.; Halme, J.; Hansen, O.; Lund, P. D.; Chorkendorff, I. Scalability and Feasibility of Photoelectrochemical $\mathrm{H}_{2}$ Evolution: The Ultimate Limit of Pt Nanoparticle as an HER Catalyst. Energy Environ. Sci. 2015, 8, 2991-2999.

(17) Wang, L.; Lin, C.; Huang, D.; Chen, J.; Jiang, L.; Wang, M.; Chi, L.; Shi, L.; Jin, J. Optimizing the Volmer Step by Single-Layer Nickel Hydroxide Nanosheets in Hydrogen Evolution Reaction of Platinum. ACS Catal. 2015, 5, 3801-3806. 
(18) Zheng, J. Seawater Splitting for High-Efficiency Hydrogen Evolution by Alloyed $\mathrm{PtNi}_{x}$ Electrocatalysts. Appl. Surf. Sci. 2017, 413, 360-365.

(19) Zhou, W.; Jia, J.; Lu, J.; Yang, L.; Hou, D.; Li, G.; Chen, S. Recent Developments of Carbon-Based Electrocatalysts for Hydrogen Evolution Reaction. Nano Energy 2016, 28, 29-43.

(20) Chakrabartty, S.; Gopinath, C. S.; Raj, C. R. Polymer-Based Hybrid Catalyst of Low Pt Content for Electrochemical Hydrogen Evolution. Int. J. Hydrogen Energy 2017, 42, 22821-22829.

(21) Nazir, R.; Fageria, P.; Basu, M.; Pande, S. Decoration of Carbon Nitride Surface with Bimetallic Nanoparticles $(\mathrm{Ag} / \mathrm{Pt}, \mathrm{Ag} / \mathrm{Pd}$, and $\mathrm{Ag} / \mathrm{Au})$ via Galvanic Exchange for Hydrogen Evolution Reaction. J. Phys. Chem. C 2017, 121, 19548-19558.

(22) Devadas, B.; Imae, T. Hydrogen Evolution Reaction Efficiency by Low Loading of Platinum Nanoparticles Protected by Dendrimers on Carbon Materials. Electrochem. Commun. 2016, 72, 135-139.

(23) Wu, M.; Shen, P. K.; Wei, Z.; Song, S.; Nie, M. High Activity PtPd-WC/C Electrocatalyst for Hydrogen Evolution Reaction. J. Power Sources 2007, 166, 310-316.

(24) Chen, J.; Yang, Y.; Su, J.; Jiang, P.; Xia, G.; Chen, Q. Enhanced Activity for Hydrogen Evolution Reaction over CoFe Catalysts by Alloying with Small Amount of Pt. ACS Appl. Mater. Interfaces 2017, 9, 3596-3601.

(25) Kavian, R.; Choi, S.-I.; Park, J.; Liu, T.; Peng, H.-C.; Lu, N.; Wang, J.; Kim, M. J.; Xia, Y.; Lee, S. W. Pt-Ni Octahedral Nanocrystals as a Class of Highly Active Electrocatalysts Toward the Hydrogen Evolution Reaction in an Alkaline Electrolyte. J. Mater. Chem. A 2016, 4, 12392-12397.

(26) Wang, S.; Yang, G.; Yang, S. Pt-Frame@Ni quasi Core-Shell Concave Octahedral $\mathrm{PtNi}_{3}$ Bimetallic Nanocrystals for Electrocatalytic Methanol Oxidation and Hydrogen Evolution. J. Phys. Chem. C 2015, 119, 27938-27945.

(27) Luo, Y.; Huang, D.; Li, M.; Xiao, X.; Shi, W.; Wang, M.; Su, J.; Shen, Y. $\mathrm{MoS}_{2}$ Nanosheet Decorated with Trace Loads of Pt as Highly Active Electrocatalyst for Hydrogen Evolution Reaction. Electrochim. Acta 2016, 219, 187-193.

(28) Deng, J.; Li, H.; Xiao, J.; Tu, Y.; Deng, D.; Yang, H.; Tian, H.; Li, J.; Ren, P.; Bao, X. Triggering the Electrocatalytic Hydrogen Evolution Activity of the Inert Two-Dimensional $\mathrm{MoS}_{2}$ Surface via Single-Atom Metal Doping. Energy Environ. Sci. 2015, 8, 1594-1601.

(29) Bai, S.; Wang, C.; Deng, M.; Gong, M.; Bai, Y.; Jiang, J.; Xiong, Y. Surface Polarization Matters: Enhancing the Hydrogen-Evolution Reaction by Shrinking $\mathrm{Pt}$ Shells in $\mathrm{Pt}-\mathrm{Pd}-\mathrm{Graphene}$ Stack Structures. Angew. Chem., Int. Ed. 2014, 53, 12120-12124.

(30) Yin, J.; Fan, Q.; Li, Y.; Cheng, F.; Zhou, P.; Xi, P.; Sun, S. Ni$\mathrm{C}-\mathrm{N}$ Nanosheets as Catalyst for Hydrogen Evolution Reaction. J. Am. Chem. Soc. 2016, 138, 14546-14549.

(31) Rowley-Neale, S. J.; Brownson, D. A. C.; Smith, G. C.; Sawtell, D. A. G.; Kelly, P. J.; Banks, C. E. 2D Nanosheet Molybdenum Disulphide $\left(\mathrm{MoS}_{2}\right)$ Modified Electrodes Explored Towards the Hydrogen Evolution Reaction. Nanoscale 2015, 7, 18152-18168.

(32) Senthilkumar, B.; Khan, Z.; Park, S.; Kim, K.; Ko, H.; Kim, Y. Highly Porous Graphitic Carbon and $\mathrm{Ni}_{2} \mathrm{P}_{2} \mathrm{O}_{7}$ for a High Performance Aqueous Hybrid Supercapacitor. J. Mater. Chem. A 2015, 3, 21553-21561.

(33) de Lima, F.; Maia, G. Oxidized/Reduced Graphene Nanoribbons Facilitate Charge Transfer to the $\mathrm{Fe}(\mathrm{CN})_{6}{ }^{3-} / \mathrm{Fe}(\mathrm{CN})_{6}^{4-}$ Redox Couple and towards Oxygen Reduction. Nanoscale 2015, 7, 61936207.

(34) Chen, D.; Tao, Q.; Liao, L. W.; Liu, S. X.; Chen, Y. X.; Ye, S. Determining the Active Surface Area for Various Platinum Electrodes. Electrocatalysis 2011, 2, 207-219.

(35) Green, C. L.; Kucernak, A. Determination of the Platinum and Ruthenium Surface Areas in Platinum-Ruthenium Alloy Electrocatalysts by Underpotential Deposition of Copper. I. Unsupported Catalysts. J. Phys. Chem. B 2002, 106, 1036-1047.

(36) Angerstein-Kozlowska, H. Surfaces, Cells, and Solutions for Kinetic Studies. In Comprehensive Treatise of Electrochemistry; Yearger,
E., Bockris, J. O’M., Conway, B. E., Sarangapani, S., Eds.; Plenum Press: New York, 1984; Vol. 9, Chapter 2, pp 15-59.

(37) McCrory, C. C. L.; Jung, S.; Peters, J. C.; Jaramillo, T. F. Benchmarking Heterogeneous Electrocatalysts for the Oxygen Evolution Reaction. J. Am. Chem. Soc. 2013, 135, 16977-16987.

(38) Jayaraman, T.; Raja, S. A.; Priya, A.; Jagannathan, M.; Ashokkumar, M. Synthesis of a Visible-Light Active $\mathrm{V}_{2} \mathrm{O}_{5}-\mathrm{g}-\mathrm{C}_{3} \mathrm{~N}_{4}$ Heterojunction as an Efficient Photocatalytic and Photoelectrochemical Material. New J. Chem. 2015, 39, 1367-1374.

(39) Theerthagiri, J.; Senthil, R. A.; Priya, A.; Madhavan, J.; Michael, R. J. V.; Ashokkumar, M. Photocatalytic and Photoelectrochemical Studies of Visible-Light Active $\alpha-\mathrm{Fe}_{2} \mathrm{O}_{3}-\mathrm{g}-\mathrm{C}_{3} \mathrm{~N}_{4}$ Nanocomposites. RSC Adv. 2014, 4, 38222-38229.

(40) Theerthagiri, J.; Senthil, R. A.; Arunachalam, P.; Madhavan, J.; Buraidah, M. H.; Amutha, S.; Arof, A. K. Synthesis of Various Carbon Incorporated Flower-Like $\mathrm{MoS}_{2}$ Microspheres as Counter Electrode for Dye-Sensitized Solar Cells. J. Solid State Electrochem. 2017, 21, $581-590$.

(41) Theerthagiri, J.; Thiagarajan, K.; Senthilkumar, B.; Khan, Z.; Senthil, R. A.; Arunachalam, P.; Madhavan, J.; Ashokkumar, M. Synthesis of Hierarchical Cobalt Phosphate Nanoflakes and Their Enhanced Electrochemical Performances for Supercapacitor Applications. ChemistrySelect 2017, 2, 201-210.

(42) Theerthagiri, J.; Senthil, R. A.; Buraidah, M. H.; Raghavender, M.; Madhavan, J.; Arof, A. K. Synthesis and Characterization of $\left(\mathrm{Ni}_{1-\mathrm{x}} \mathrm{Co}_{\mathrm{x}}\right) \mathrm{Se}_{2}$ Based Ternary Selenides as Electrocatalyst for Triiodide Reduction in Dye-Sensitized Solar Cells. J. Solid State Chem. 2016, 238, 113-120.

(43) Venarusso, L. B.; Bettini, J.; Maia, G. Superior Catalysts for Oxygen Reduction Reaction Based on Porous Nanostars of a Pt, Pd, or Pt-Pd Alloy Shell Supported on a Gold Core. ChemElectroChem 2016, 3, 749-756.

(44) Venarusso, L. B.; Bettini, J.; Maia, G. Catalysts for Oxygen Reduction Reaction Based on Nanocrystals of a Pt or Pt-Pd Alloy Shell Supported on a Au Core. J. Solid State Electrochem. 2016, 20, $1753-1764$

(45) Fortunato, G. V.; de Lima, F.; Maia, G. Oxygen-Reduction Reaction Strongly Electrocatalyzed by $\mathrm{Pt}$ Electrodeposited onto Graphene or Graphene Nanoribbons. J. Power Sources 2016, 302, 247-258.

(46) Boone, C. V.; Maia, G. Pt-Pd and Pt-Pd-(Cu or Fe or Co)/ Graphene Nanoribbon Nanocomposites as Efficient Catalysts Toward the Oxygen Reduction Reaction. Electrochim. Acta 2017, 247, 19-29.

(47) Venarusso, L. B.; Boone, C. V.; Bettini, J.; Maia, G. CarbonSupported Metal Nanodendrites as Efficient, Stable Catalysts for the Oxygen Reduction Reaction. J. Mater. Chem. A 2018, 6, 1714-1726.

(48) Koyama, Y.; Mizoguchi, T.; Ikeno, H.; Tanaka, I. Electronic Structure of Lithium Nickel Oxides by Electron Energy Loss Spectroscopy. J. Phys. Chem. B 2005, 109, 10749-10755.

(49) Keast, V. J.; Scott, A. J.; Brydson, R.; Williams, D. B.; Bruley, J. Electron Energy-Loss Near-Edge Structure - A Tool for the Investigation of Electronic Structure on the Nanometre Scale. J. Microsc. 2001, 203, 135-175.

(50) Favron, A.; Gaufrès, E.; Fossard, F.; Phaneuf-L'Heureux, A.-L.; Tang, N. Y-W.; Lévesque, P. L.; Loiseau, A.; Leonelli, R.; Francoeur, S.; Martel, R. Photooxidation and Quantum Confinement Effects in Exfoliated Black Phosphorus. Nat. Mater. 2015, 14, 826-832.

(51) Wu, R. J.; Topsakal, M.; Low, T.; Robbins, M. C.; Haratipour, N.; Jeong, J. S.; Wentzcovitch, R. M.; Koester, S. J.; Mkhoyan, K. A. Atomic and Electronic Structure of Exfoliated Black Phosphorus. J. Vac. Sci. Technol. A 2015, 33, 060604.

(52) Wulan, B.-R.; Yi, S.-S.; Li, S.-J.; Duan, Y.-X.; Yan, J.-M.; Jiang, Q. Amorphous Nickel Pyrophosphate Modified Graphitic Carbon Nitride: An Efficient Photocatalyst for Hydrogen Generation from Water Splitting. Appl. Catal., B 2018, 231, 43-50.

(53) Sankar, K. V.; Seo, Y.; Lee, S. C.; Jun, S. C. Redox AdditiveImproved Electrochemically and Structurally Robust Binder-Free Nickel Pyrophosphate Nanorods as Superior Cathode for Hybrid Supercapacitors. ACS Appl. Mater. Interfaces 2018, 10, 8045-8056. 
(54) Chen, C.; Zhang, N.; He, Y.; Liang, B.; Ma, R.; Liu, X. Controllable Fabrication of Amorphous Co-Ni Pyrophosphates for Tuning Electrochemical Performance in Supercapacitors. ACS Appl. Mater. Interfaces 2016, 8, 23114-23121.

(55) Zhang, N.; Chen, C.; Chen, Y.; Chen, G.; Liao, C.; Liang, B.; Zhang, J.; Li, A.; Yang, B.; Zheng, Z.; Liu, X.; Pan, A.; Liang, S.; Ma, R. $\mathrm{Ni}_{2} \mathrm{P}_{2} \mathrm{O}_{7}$ Nanoarrays with Decorated $\mathrm{C}_{3} \mathrm{~N}_{4}$ Nanosheets as Efficient Electrode for Supercapacitors. ACS Appl. Energy Mater. 2018, 1, 2016-2023.

(56) Zheng, J.; Yan, Y.; Xu, B. Correcting the Hydrogen Diffusion Limitation in Rotating Disk Electrode Measurements of Hydrogen Evolution Reaction Kinetics. J. Electrochem. Soc. 2015, 162, F1470F1481.

(57) Chen, J. G.; Jones, C. W.; Linic, S.; Stamenkovic, V. R. Best Practices in Pursuit of Topics in Heterogeneous Electrocatalysis. ACS Catal. 2017, 7, 6392-6393.

(58) Chen, R.; Yang, C.; Cai, W.; Wang, H.-Y.; Miao, J.; Zhang, L.; Chen, S.; Liu, B. Use of Platinum as the Counter Electrode to Study the Activity of Nonprecious Metal Catalysts for the Hydrogen Evolution Reaction. ACS Energy Lett. 2017, 2, 1070-1075.

(59) Wei, R.; Fang, M.; Dong, G.; Ho, J. C. Is Platinum a Suitable Counter Electrode Material for Electrochemical Hydrogen Evolution Reaction? Sci. Bull. 2017, 62, 971-973.

(60) Neyerlin, K. C.; Gu, W.; Jorne, J.; Gasteiger, H. A. Study Of The Exchange Current Density for the Hydrogen Oxidation and Evolution Reactions. J. Electrochem. Soc. 2007, 154, B631-B635.

(61) Meguerdichian, A. G.; Jafari, T.; Shakil, M. R.; Miao, R.; Achola, L. A.; Macharia, J.; Shirazi-Amin, A.; Suib, S. L. Synthesis and Electrocatalytic Activity of Ammonium Nickel Phosphate, $\left[\mathrm{NH}_{4}\right]$ $\mathrm{NiPO}_{4} \cdot 6 \mathrm{H}_{2} \mathrm{O}$, and $\beta$-Nickel Pyrophosphate, $\beta-\mathrm{Ni}_{2} \mathrm{P}_{2} \mathrm{O}_{7}$ : Catalysts for Electrocatalytic Decomposition of Urea. Inorg. Chem. 2018, 57, $1815-1823$.

(62) Li, K.; Li, Y.; Wang, Y.; Ge, J.; Liu, C.; Xing, W. Enhanced Electrocatalytic Performance for the Hydrogen Evolution Reaction Through Surface Enrichment of Platinum Nanoclusters Alloying with Ruthenium in Situ Embedded in Carbon. Energy Environ. Sci. 2018, $11,1232-1239$.

(63) Ji, S.; Yang, Z.; Zhang, C.; Liu, Z.; Tjiu, W. W.; Phang, I. Y.; Zhang, Z.; Pan, J.; Liu, T. Exfoliated $\mathrm{MoS}_{2}$ Nanosheets as Efficient Catalysts for Electrochemical Hydrogen Evolution. Electrochim. Acta 2013, 109, 269-275.

(64) Pu, Z.; Liu, Q.; Asiri, A. M.; Luo, Y.; Sun, X.; He, Y. 3D Macroporous $\mathrm{MoS}_{2}$ Thin Film: In Situ Hydrothermal Preparation and Application as a Highly Active Hydrogen Evolution Electrocatalyst at All pH Values. Electrochim. Acta 2015, 168, 133-138.

(65) Vesborg, P. C. K.; Seger, B.; Chorkendorff, I. Recent Development in Hydrogen Evolution Reaction Catalysts and Their Practical Implementation. J. Phys. Chem. Lett. 2015, 6, 951-957.

(66) Trasatti, S. Work Function, Electronegativity, and Electrochemical Behaviour of Metals: III. Electrolytic Hydrogen Evolution in Acid Solutions. J. Electroanal. Chem. Interfacial Electrochem. 1972, 39, $163-184$.

(67) Zou, X.; Zhang, Y. Noble Metal-Free Hydrogen Evolution Catalysts for Water Splitting. Chem. Soc. Rev. 2015, 44, 5148-5180. 